



\section{Læsefærdigheder i Norden - Studie 4}

Lisbeth Lentz og Charlotte Rotbøll

Danmarks Evalueringsinstitut

TemaNord 2006:577 


\section{Læsefærdigheder i Norden - Studie 4}

TemaNord 2006:577

(C) Nordisk Ministerråd, København 2006

ISBN 92-893-1393-5

Tryk: Ekspressen Tryk \& Kopicenter

Omslag: Kjell Olsson

Oplag: 200

Trykt på miljøvenligt papir som opfylder kravene i den nordiske miljøsvanemærkeordning.

Publikationen kan bestilles på www.norden.org/order. Flere publikationer på

www.norden.org/publikationer

Printed in Denmark

Nordisk Ministerråd

Store Strandstræde 18

1255 København K

Telefon (+45) 33960200

Fax (+45) 33960202

\author{
Nordisk Råd \\ Store Strandstræde 18 \\ 1255 København K \\ Telefon (+45) 33960400 \\ Fax (+45) 33111870
}

\section{www.norden.org}

\section{Det nordiske samarbejde}

Det nordiske samarbejde er et af de ældste og mest omfattende regionale samarbejder i verden. Det omfatter Danmark, Finland, Island, Norge og Sverige samt Færøerne, Grønland og Åland. Samarbejdet styrker samhørigheden mellem de nordiske lande med respekt for de nationale forskelle og ligheder. Det øger mulighederne for at hævde Nordens interesser i omverdenen og fremme det gode naboskab.

Samarbejdet blev formaliseret i 1952 med Nordisk Råds oprettelse som forum for parlamentarikerne og regeringerne i de nordiske lande. I 1962 underskrev de nordiske lande Helsingforsaftalen, som siden har været den grundlæggende ramme for det nordiske samarbejde. I $1971 \mathrm{blev}$ Nordisk Ministerråd oprettet som det formelle forum til at varetage samarbejdet mellem de nordiske regeringer og de politiske ledelser i de selvstyrende områder, Færøerne, Grønland og Åland. 


\section{Förord}

Läsfärdigheter är en avgörande faktor för skolframgång och framgång senare i arbetslivet och därmed också för Nordens möjligheter att möta framtida utmaningar i att lösa samhällsproblem eller utveckla Nordens konkurrensförmåga.

Internationella läsundersökningar visar att eleverna från de nordiska länderna inte alla är lika goda i läsning. Det finns stora skillnader mellan pojkars och flickors läsfärdigheter och de nordiska länderna skiljer sig negativt ut i detta sammanhang i förhållande till det övriga Europa. De nordiska pojkarna klarar sig sämre än flickorna och skillnaderna ser ut att öka. Mot denna bakgrund har det norska ordförandeskapet i Nordiska ministerrådet tagit initiativ till denna studie som analyserar läsfärdigheter i Norden i ett könsperspektiv.

Föremålet med studien om läsfärdigheter i Norden har varit att skissera problemställningar i relation till skillnader i pojkars och flickors läsfärdigheter samt identifiera speciella insatsområden för Nordiska ministerrådet med hänsyn till framtida aktiviteter och nordiska undersökningar. Det är väldokumenterat att det finns stora skillnader i läsning och det existera olika redogörelser för möjliga förklaringar på skillnader, det har däremot inte funnits en nordisk översikt över relevant forskning gällande läsning och könsskillnader.

Genom att ta utgångspunkt i resultaten från internationella läsundersökningar, bland annat PISA analyserar studien grundskoleelevernas läsfärdigheter i Norden och orsakerna till att det finns skillnader mellan de nordiska länderna och mellan könen. Förklaringsfaktorerna till resultaten från läsundersökningarna har därefter jämförts med andra nordiska undersökningar och relevant forskning. Studien lyfter fram faktorer som är relaterade till tre nivåer: systemnivå, skolnivå och elevnivå. Studien framlägger förslag på vilka områden man i framtiden kan undersöka när- 
mare, bland annat föreslås det att de nordiska länderna bör se närmare på hur forskningsresultat bättre kan förankras i skolorna. Jag hoppas att studien kan bidra till vidareutveckling av det nordiska samarbetet kring läsfärdigheter och ge inspel till framtida undersökningar på området.

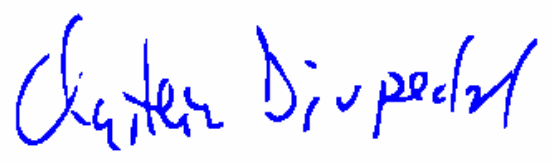

\section{Øystein Djupedal \\ Kunnskapsminister}




\section{Læsefærdigheder I Norden}

Læsefærdigheder er helt centrale for samfund som de nordiske, særligt når man søger at etablerer sig som videnssamfund. Dette studie konstaterer, at eleverne fra de nordiske lande ikke alle er lige gode til at læse. Der konkluderes endvidere en interessant forskel i de nordiske pigers og drenges læsefærdigheder - hvor drengene markerer sig ved at halte endnu længere bagud. I denne sammenhæng skiller de nordiske lande sig negativt ud i forhold til resten af Europa. Studiet anbefaler enkelte indsatsområder som eventuelt kan styrkes gennem nordisk samarbejde.

Studiet er udarbejdet for Nordisk Ministerråd af Danmarks Evalueringsinstitut, som har fået faglig støtte fra en referencegruppe bestående af repræsentanter fra Nordisk Ministerråds styregruppe for nordisk skolesamarbejde (NSS).

\section{Nordisk Ministerråds studieserie: Norden som global vinderegion}

Nordisk Ministerråd for uddannelse og forskning har under Norges formandskab ønsket at identificere udviklingsmuligheder på politikområder, som har en særlig relevans for de nordiske lande, i lyset af den stigende globalisering og det øget pres på de nordiske landes økonomiske konkurrenceevne. Interessen for sådanne problemstillinger og den deraf følgende nødvendige politikudvikling, nationalt og eventuelt samnordisk, tager afsæt i et debatoplæg som Ministerrådet fik udarbejdet med titlen „Norden som global vinderegion“ ${ }^{1}$. Oplæget konkluderer en række særlige nordiske styrkepositioner og fremfører en række konkrete politiske anbefalinger. Ministerrådet har i forlængelse heraf valgt at ser nærmere på særligt fire politikområder, som på forskellig vis forskellig synes vigtige for at de nordiske lande kan styrke deres positioner som vidensøkonomier.

Studierne er ikke udtryk Ministerrådets politik eller positioner, men blot udtryk for at man finder behov for yderligere at diskuterer deres politiske implikationer. Fire uafhængige studier er således blevet gennemført, og udgives nu under en fælles temaoverskrift „Norden som global vinderegion“:

Fortsættes

\footnotetext{
${ }^{1}$ Norden som global vinderegion: http://www.norden.org/webb/pressrelease/ pressrelease. .asp?id $=1275$
} 


\section{Fortsat}

1. Nordisk Innovationskraft - Strategier og virkemidler til øget samspil mellem forskning og erhvervsliv i de nordiske lande

2. Nordisk kvalitetssikring av høyere utdanning. Muligheter for gjensidig godkjenning og økt samarbeid.

3. Building Nordic Strength Through More Open R\&D Funding - The Next Step in NORIA.

4. Læsefærdigheder i Norden 


\section{Indholdsfortegnelse}

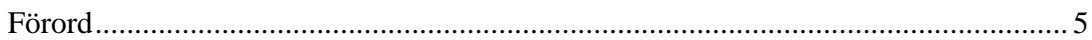

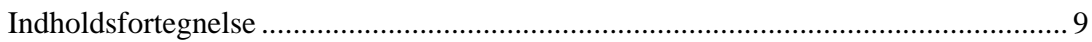

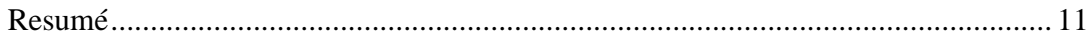

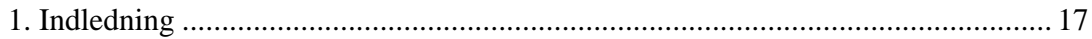

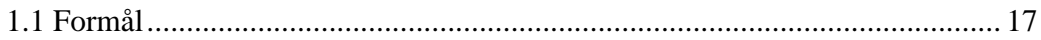

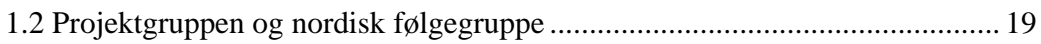

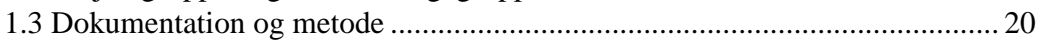

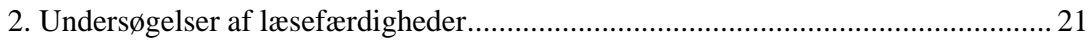

2.1 Udvælgelse og sammenlignelighed........................................................ 21

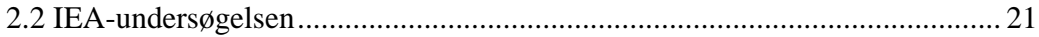

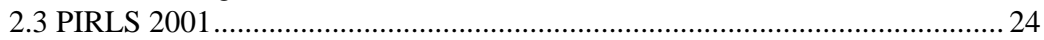

2.4 Trendstudiet: Fra IEA 1991 til PIRLS 2001................................................. 26

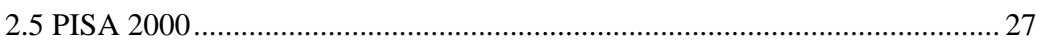

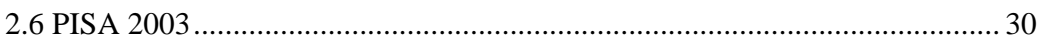

2.7 Forskelle i prøvematerialet fra IEA til PISA ................................................. 31

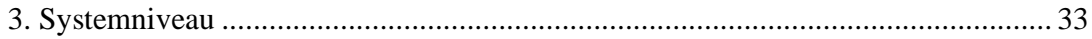

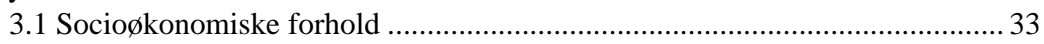

3.1.1 Forældrenes uddannelsesmæssige baggrund................................. 34

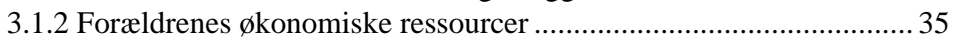

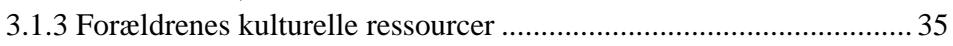

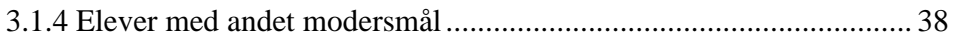

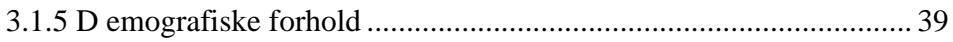

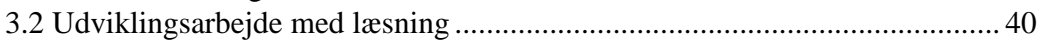

3.2.1 Forskning og forankring på skoleniveau ........................................... 41

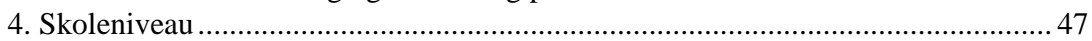

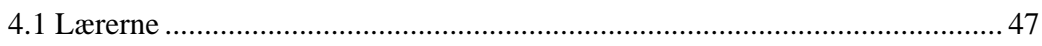

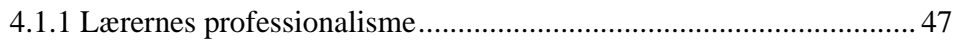

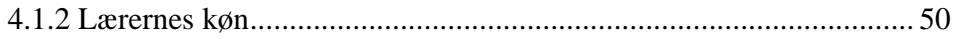

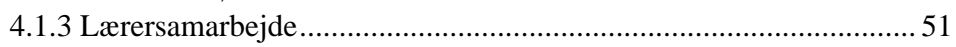

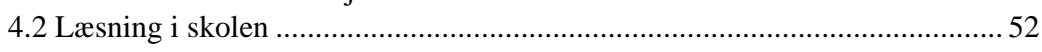

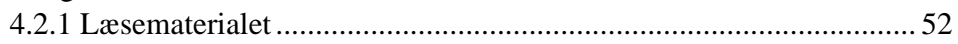

4.2.2 Læsetid......................................................................................... 53

4.2.3 Arbejdet med læsning ................................................................. 54

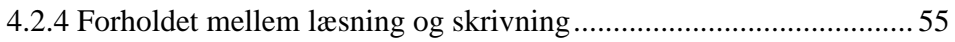

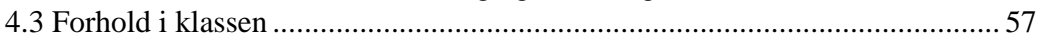

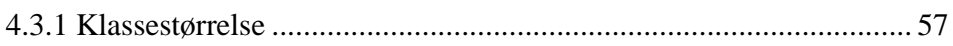




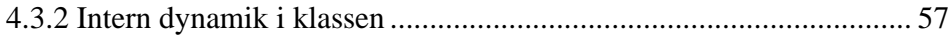

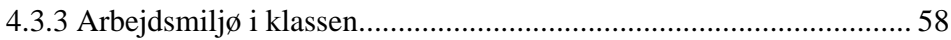

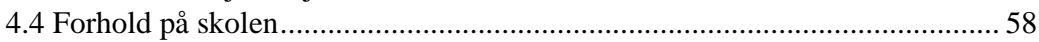

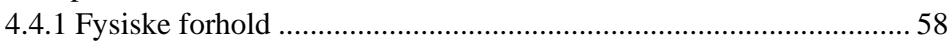

4.4.2 Skolens læringsmiljø................................................................ 59

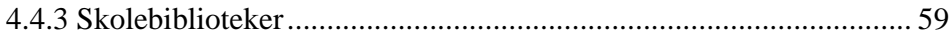

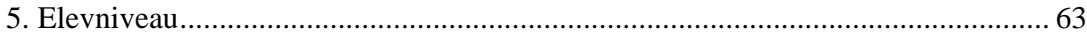

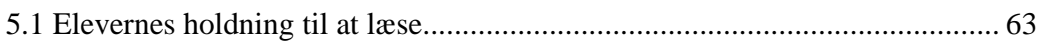

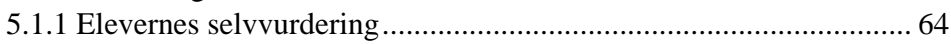

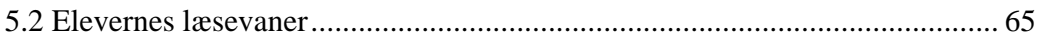

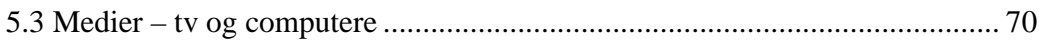

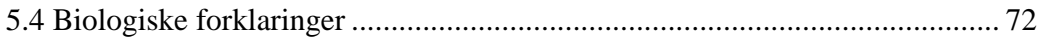

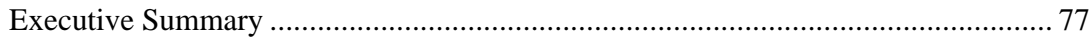

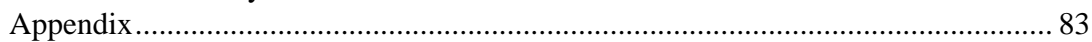

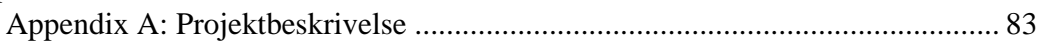

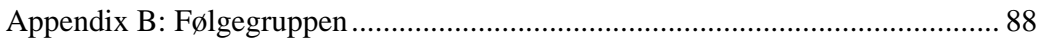




\section{Resumé}

Denne rapport analyserer grundskoleelevernes læsefærdigheder i Norden og hvad der er årsagen til at der er forskelle i læsefærdigheder mellem landene og mellem kønnene.

Nordisk Ministerråd har rekvireret analysen hos Danmarks Evalueringsinstitut (EVA). Baggrunden for analysen er de nordiske elevers præstation i PISA-undersøgelserne. Elevernes læsefærdigheder er belyst gennem de internationale læseundersøgelser fra IEA og PISA siden 1991. Forklaringsfaktorerne bag resultaterne fra læseundersøgelserne er efterfølgende analyseret med afsæt i andre nordiske undersøgelser og relevant forskning.

Dette resumé gør kort rede for resultaterne fra de internationale undersøgelser og fremsætter forslag til hvilke områder man i fremtiden kan undersøge og sætte ind på for at fremme elevernes læsefærdigheder og for at mindske forskellene mellem drenges og pigers færdigheder.

\section{Nordiske elevers læeseferdigheder}

De internationale læseundersøgelser viser at eleverne fra de nordiske lande ikke er lige gode til at læse. I Norge og Danmark er elevernes læsefærdigheder gennemsnitlige i forhold til de internationale sammenligninger, mens svenske og islandske elever placerer sig pænt i den bedre halvdel - de svenske elever læser bedst. Endelig viser undersøgelserne at de finske elever klarer sig internationalt bedre end elever fra alle de andre lande i læseundersøgelserne.

Læseundersøgelserne viser også at pigerne læser bedre end drengene, og at forskellen mellem drenges og pigers læsefærdigheder er store i de nordiske lande, ikke mindst når man sammenligner med de øvrige euro- 
pæiske og oversøiske lande. Imidlertid er forskellen mellem drenges og pigers læsefærdigheder nogenlunde lige stor i alle nordiske lande.

\section{Den socioøkonomiske baggrunds betydning for leesefcerdigheder}

De internationale undersøgelser viser at den sociale arv langtfra bliver brudt i skolesystemet i de nordiske lande - især har forældrenes uddannelsesniveau stor betydning for elevernes præstationer i læsetestene. Imidlertid er niveauerne for elevernes læsefærdigheder meget forskellige i de nordiske lande. Denne rapport og andre tidligere undersøgelser konkluderer at en af årsagerne til den finske succes inden for læsning er at skolerne formår at reducere påvirkningerne fra den sociale arv. Analyse af resultaterne fra PISA 2003 i Norge viser at den socioøkonomiske baggrund giver størst udslag blandt pigerne.

Fokusområde for fremtidige undersøgelser

Det vil være relevant at undersøge hvorfor socioøkonomiske barrierer brydes bedre i fx Finland end i de øvrige nordiske lande. Det vil også være aktuelt at undersøge hvilken betydning socioøkonomisk status har i de nordiske lande, hvordan skolerne tager højde for elevernes baggrund, og hvorfor den socioøkonomiske baggrund har større betydning for pigerne.

\section{Elevernes holdning til at lase}

I processen hvor eleverne skal lære at læse, og når de skal arbejde videre med læsningen, er det afgørende at de er engagerede og motiverede. Elevernes holdning til læsning i fritiden afspejler naturligvis i en vis grad forældrenes holdning til at læse, og den tager ofte afsæt i deres socioøkonomiske baggrund. Selv om de to ting ofte er forbundet, har elevernes holdning til det at læse større betydning end socioøkonomiske forhold den sociale arv kan således brydes ved at give eleverne en mere positiv holdning til at læse.

Forskellen mellem drenge og piger kommer også tydeligt til udtryk når det gælder holdning til læsningen. Piger er mere positivt indstillet end drenge over for læsning i fritiden, og det er en vigtig forklaring på de store forskelle i læsepræstationerne. 
Fokusområde for fremtidige undersøgelser

Det vil være relevant at undersøge og analysere hvordan man motivere drenge til læse, og hvilken målrettet indsats der kan fremme deres læselyst. Kampagnerne kan bidrage til mere læselyst og dermed til bedre læsefærdigheder og bør primært rettes mod drengene. Udbredelse af større læseengagement til alle elever bidrager desuden til at bryde den sociale arv.

Bibliotekers betydning for laesning

Biblioteker spiller en væsentlig rolle for elevernes adgang til bøger. I Finland og Danmark har man et meget udbygget og tilgængeligt folkebibliotek, og eleverne i begge lande bruger det flittigt. Elevernes meget forskellige læseresultater i de to lande viser imidlertid at der ikke er sammenhæng mellem elevernes anvendelse af biblioteker og læsefærdigheder.

Fokusområde for fremtidige undersøgelser

Det vil være relevant at undersøge forskellen i biblioteksvaner i de nordiske lande og afdække hvorfor de danske elevers lån af bøger ikke giver de samme læseresultater som hos de finske elever.

Forskning og forskningens forankring på skolerne

Nordiske undersøgelser og evalueringer viser at systematisk forskning på området er en forudsætning for at kunne opnå ny viden om læsning. Det er også vigtigt at forskningsindsatsen er forankret på skolerne så den kan støtte lærernes faglige grundlag og øge deres professionalisme.

Flere af de nordiske lande har allerede og har i mange år haft en systematiseret forskning på læseområdet. Norges læsecenter i Stavanger er et godt eksempel. I Danmark har man i derimod traditionelt investeret langt færre ressourcer i forskningen i læsning og nu har anbefalinger fra Læseudvalget gjort det til et prioriteret fokusområde.

Erfaringer fra EVA's evalueringer af læsning i den danske folkeskole viser at læsekonsulenter i kommunerne fungerer godt som brobyggere mellem forskning og praksis, og at det er en funktion som med fordel vil kunne udbygges. Læsekonsulenterne udgør samtidig en oplagt mulighed 
for at udveksle erfaringer gennem nordiske netværk ved at de både kan indsamle og videreformidle forskning og gode erfaringer fra praksis på andre skoler. En forankring af viden genereret fra forskning kan samtidig understøtte en øget professionalisme hos lærerne.

Fokusområde for fremtidige undersøgelser

De nordiske lande vil kunne nyde godt af at samarbejde i nordiske netværk om forskning på skoleområdet generelt og om læsning specifikt. Dette gælder især på praksisniveau i forhold til at omsætte forskningsresultater til nye praksisser på de enkelte skoler. Det vil være relevant at se på hvordan forskning kan forankres bedre på skoleniveau. Det vil også være aktuelt at overveje hvordan de nordiske lande kan blive bedre til at samarbejde i netværk på både forsker- og praksisniveau.

\section{Lærernes professionalisme}

Analysen viser at lærernes erfaringer og uddannelse er vigtigt i forhold til læseundervisning af flere grunde. Lærere med de rette kvalifikationer mindsker risikoen for at elever havner i onde cirkler hvor læsning er og bliver en indviklet og lang proces. Desuden kan kvalificerede lærer tage hensyn til drenges og pigers forskellige behov i undervisningen.

Fokusområde for fremtidige undersøgelser

Det vil være relevant at se på hvilke lærerkompetencer der kræves i læseundervisningen på forskellige niveauer i grundskolen, og på den baggrund undersøge hvordan man kan sikre at lærerne har de relevante kvalifikationer.

\section{Samarbejde i faglige miljøer}

Lærernes faglige samarbejde er vigtigt for at sikre deres kvalifikationer og er derfor centralt for kvaliteten af læseundervisningen. Evalueringen af læsning i den danske folkeskole viser at lærerne savner læsefaglige miljøer på skolerne. 
Fokusområde for fremtidige undersøgelser

Det vil være relevant at undersøge hvordan samarbejdet generelt fungerer på skoleniveau. Man bør blandt andet fokusere på hvordan samarbejdet kan hjælpe læseundervisningen i en positiv retning gennem bedre læsefaglige miljøer på skolerne.

\section{Lesematerialet}

Undersøgelserne viser at læsematerialet er afgørende for elevernes læsning. Samtlige undersøgelser viser at drenge især er dårlige til at læse skønlitterære tekster, mens de er relativt bedre til at læse skematiserede tekster som tabeller og grafer. Emnerne i teksterne har også betydning for forskelle i læsefærdighederne. Piger klarer sig bedst når handlingen i teksten er relateret til mennesker - enten med mennesker som hovedpersoner eller dyr der handler som mennesker. Drengene klarer sig derimod relativt bedre med tekster uden mennesker - $\mathrm{fx}$ om naturvidenskabelige emner.

Læseundervisningen i de nordiske lande er ofte centreret omkring skønlitterære tekster med børn som hovedpersoner. Da netop den form for læsemateriale appellerer mindre til drenge end til piger, er det tydeligt at læseundervisningen i dag mange steder ikke motiverer drengene optimalt.

Fokusområde for fremtidige undersøgelser

Det vil være relevant at undersøge hvilket materiale som i højere grad motiverer drengene - og hvordan det kan inddrages bedre i undervisningen.

\section{Arbejdet med lasning}

At bearbejde det læste er ifølge flere læseforskere centralt for at udvikle læsefærdigheder. Øvelser der øger forståelsen af en tekst karakteriseres ved at eleven omformulerer det læste med sine egne ord. Denne øvelse kan foregå både mundtligt og skriftligt, individuelt, i grupper eller som klasseundervisning.

Med hensyn til forholdet mellem læsning og skrivning har opfattelsen traditionelt været at læsning er en forudsætning for skrivning. Læseforskere har imidlertid sået tvivl om denne opfattelse ud fra en mere cirkulær 
opfattelse af læseindlæring hvor flere processer forløber samtidig - og hvor det tværtimod kan være en fordel at begynde med at lære at skrive lyde. I denne forbindelse kan brugen af it også være vigtig fordi drengene kan begynde læseindlæringen ved computeren frem for med en bog.

Fokusområde for fremtidige undersøgelser

Det vil være relevant at se på hvilke muligheder som er særligt velegnede for drenge der måske vil have nemmere ved at forklare en tekst ved at tegne den end ved at skrive om den. 


\section{Indledning}

Læsning er den vigtigste færdighed som elever skal opnå i de første skoleår. Gode læsefærdigheder er en forudsætning for at kunne tilegne sig kundskaber inden for andre fagområder og er derfor også en af de vigtigste faktorer for valg af uddannelse og erhverv efter grundskolen. Gode læsefærdigheder er desuden afgørende for at kunne fungere som demokratisk borger i informationssamfundet hvor evnen til at kunne tilegne sig viden gennem skriftligt materiale er central.

Internationale læseundersøgelser viser imidlertid at der er store forskelle i hvordan jævnaldrende elever læser i de nordiske lande. Undersøgelserne viser også at der er store forskelle på pigers og drenges læsefærdighederne, og at de nordiske lande skiller sig negativt ud i denne sammenhæng i forhold til resten af Europa. De nordiske drenge klarer sig dårligere end pigerne i undersøgelserne, og det ser ud til at forskellen øges i disse år. På den baggrund har Nordisk Ministerråd taget initiativ til denne analyse af læsefærdigheder med fokus på drenge og pigers læsefærdigheder.

\subsection{Formål}

Formålet med undersøgelsen af læsning i Norden er at skitsere problemstillingerne i relation til forskelle i drenges og pigers læsefærdigheder og identificere særlige indsatsområder for Nordisk Ministerråd med henblik på fremtidige nordiske undersøgelser. Rapporten inddrager eksisterende undersøgelser af læsefærdigheder og relevant forskning på området for at afdække disse områder.

Rapporten vil præsentere en oversigt over kønsforskelle i læsefærdigheder i de nordiske lande der tager udgangspunkt i en række internationa- 
le læseundersøgelser, herunder PISA-undersøgelserne. På baggrund af disse forskelle vil rapporten gøre rede for de problemstillinger og faktorer som har betydning for læsefærdigheder. Hvor det er relevant, vil rapporten løbende fremsætte forslag til fremtidige fokusområder.

Vi har valgt at dele de faktorer der har betydning for læsefærdigheder, ind i tre niveauer: systemniveau, skoleniveau og elevniveau.

Systemniveauet er forhold på det centrale niveau der har indflydelse på børns læsefærdigheder. Forholdene falder i to dele. Den ene del handler om forældrenes socioøkonomiske status. Her indgår forældrenes uddannelsesmæssige baggrund, økonomiske og kulturelle ressourcer og forældrenes holdning til læsning. Den anden del handler om det politiske niveaus prioritering af udviklingsarbejde på læseområdet. Denne del fokuserer på forskning indenfor læseområdet, hvilket arbejde der baserer sig på resultaterne fra forskningen, og særlige udviklingsprojekter der er sat i gang.

Skoleniveauet er forhold på skolen som har betydning for elevernes udbytte af undervisningen og deres læsefærdigheder. Faktorer som har betydning på dette niveau, er først og fremmest relateret direkte til undervisningssituationen - fx lærernes uddannelsesbaggrund og arbejdet med læsning og arbejdsmiljøet i klassen. Samtidig inddrages støttefunktioner i skolen - fx skolebiblioteket.

Elevniveauet er forhold hos eleven selv og i elevens hjem som påvirker læsefærdigheden. Her er faktorerne elevens egen holdning til læsning, fx hvor meget eleven læser i fritiden, og hvor stor en rolle læsning spiller i hjemmet. På dette niveau inddrages også mere biologiske forklaringer på kønsforskellene.

\section{Afgrcensning}

Elevers læsefærdigheder og forskellene mellem drenges og pigers læsefærdigheder indeholder mange perspektiver og temaer som det er nødvendigt at prioritere og afgrænse hvis man skal have de mest centrale til at stå frem.

Da denne rapport er sat i gang på baggrund af resultaterne af PISAundersøgelserne, tager den udgangspunkt i de internationale undersøgelser fra PISA og IEA. De problematikker og faktorer der er lagt vægt på i 
rapporten, følger derfor de problematikker som man har undersøgt i disse undersøgelser.

I kapitel 4 der omhandler systemniveauet, er prioriteringen af problematikker og temaer er særligt tydelig. Kapitlet fokuserer på de socioøkonomiske forhold og på udviklingsarbejdet med læsning - herunder forskning. Det kortlægger dog ikke de lovgivningsmæssige rammer for læsning i grundskolen og deres betydning for læsefærdigheder. I stedet sigter kapitlet på inden for den lovgivningsmæssige ramme at pege på faktorer som har betydning for læseundervisningen og elevernes læsefærdigheder, og som man bør fokusere på i fremtiden - og som måske skal lede frem til en tilpasning af lovgivningen.

\subsection{Projektgruppen og nordisk følgegruppe}

\section{Projektgruppen}

Evalueringskonsulent Charlotte Rotbøll (projektleder) og evalueringsmedarbejder Jakob Lind har gennemført analysen og skrevet rapporten. Desuden har kommunikationskonsulent Charlotte Simmelhack bidraget til at afdække relevant dokumentationsmateriale, og evalueringskonsulent Per Møller Janniche har sparret i forhold til dokumentation og rapport. Områdechef Lisbet Lentz har været projektchef på undersøgelsen.

\section{Nordisk følgegruppe}

En nordisk følgegruppe har bidraget til undersøgelsen og kvalitetssikret EVA's analyse og rapport, blandt andet gennem to følgegruppemøder i København. Følgegruppen består af repræsentanter for Nordisk skolenetværk (se www.eva.dk):

- Chris Silverström, Utbildningsstyrelsen, Finland

- Tulle Schjerven, Utdanningsdirektoratet, Norge

- Karin Hector-Stahre, Skolverket, Sverige. 


\subsection{Dokumentation og metode}

Analysen er gennemført med afsæt i et tilbud som EVA afgav til Nordisk Ministerråd i december 2005. Tilbuddet (projektbeskrivelsen) beskriver EVA's erfaring med læsning og drenges og pigers præstationer i uddannelsessystemet og analysens organisering og metode. Projektbeskrivelsen kan ses i appendiks A.

Analysen er gennemført i perioden februar-april 2006 og bygger på relevante internationale test med fokus på nordiske resultater og relevante nordiske undersøgelser af læsning og læsefærdigheder. Undersøgelser af læsefærdigheder

Dette kapitel giver en oversigt over relevante internationale undersøgelser af læsefærdigheder.

Indledningsvis vil vi gøre rede for hvordan vi har udvalgt undersøgelserne og skitsere de konkrete resultater både hvad angår elevernes præstationer i de nordiske lande generelt og med særligt fokus på de forskellige resultater for drenge og piger

Kapitlet inddrager følgende fem internationale undersøgelser: IEAundersøgelsen fra 1991, PIRLS 2001 (foretaget af IEA), PIRLS trendstudie, PISA 2000 og PISA 2003 i nævnte rækkefølge. 


\section{Undersøgelser af læsefærdigheder}

\subsection{Udvælgelse og sammenlignelighed}

I analysen har vi valgt kun at medtage læseundersøgelser der minimum omfatter to nordiske lande, og som inddrager et så stort antal elever at de kan karakteriseres som repræsentative. Kriteriet for repræsentativitet er at undersøgelserne baserer sig på mindst 1000 elever pr. årgang i hvert land. I de efterfølgende kapitler inddrages nationale og mindre nordiske undersøgelser - herunder Nordlæs-undersøgelsen - som baggrund for at identificere årsagsforklaringer.

De præsenterede resultater er alle udregnet på baggrund af en Raschscore som er en point-opgørelse der kan sige noget om niveauet af læsefærdigheder i landenes indbyrdes forhold - blandt andet kønsforskellen. Prøvematerialet som undersøgelserne er baseret på, er dog forskelligt, og derfor er det ikke muligt at spore udviklingstendenser eller at tale om en større eller mindre kønsforskelle på tværs af undersøgelserne.

\subsection{IEA-undersøgelsen}

The International Association for the Evaluation of Educational Achievement (IEA) var de første til at foretage en omfattende international undersøgelse af børns læsefærdigheder - i alt 27 lande deltog. Undersøgelsen var som forgænger for PISA-undersøgelserne en af de første større internationale undersøgelser af læsefærdigheder og var på dette tidspunkt exceptionel i sit omfang. Den har siden givet anledning til stor debat i de nordiske lande samt flere efterfølgende nationale og nordiske undersøgelser. Indsamlingen af materialet til undersøgelsen fandt sted i 1991 på baggrund af en internationalt udviklet læseprøve. 
Undersøgelsen tester skolebørn i to aldersgrupper: 9-årige og 14-årige. Eleverne er valgt ud fra hvor i skolesystemet man typisk befinder sig i denne alder. Det giver en aldersusikkerhed i forhold til hvornår børn har påbegyndt skolegangen, og om de er gået klasser om (Mejding, 1994 - se også her for en nærmere diskussion af problematikken).

\section{Testmaterialet fra IEA}

I IEA-undersøgelsen indgår tre forskellige teksttyper (Mejding, 1994):

- Skønlitterære tekster. Teksterne indeholder som regel et tidsforløb og fortæller en sammenhængende historie.

- Faglitterære tekster. Teksterne er sammenhængende tekster som skal give faktuelle oplysninger.

- Skematiserede tekster. Teksterne er udformet som grafer, tabeller, kort eller vejledninger som ikke er beregnet til en sammenhængende gennemlæsning.

\section{De nordiske landes prcestationer i IEA}

De nordiske lande klarer sig alle, på nær Danmark, overordnet pænt for både de 9-årige og de 14-åriges vedkommende - særligt Finland og Sverige klarer sig godt.

For de 9-årige placerer Finland og Sverige sig helt i top som henholdsvis nummer 1 og 3 . Norge og Island klarer sig næsten lige godt og placerer sig pænt over gennemsnittet. Danmark klarer sig derimod mindre godt med en placering i bunden som nummer 24 .

For de 14-årige var billedet i toppen det samme med Finland og Sverige som nummer 1 og 3, og Island ligger også her over gennemsnittet. Danmark klarer sig for de 14-åriges vedkommende bedre end for de 9åriges og placerer sig omkring gennemsnittet, lige over Norge hvor de 14årige placerer sig en smule dårligere end de 9-årige (Elley, 1992).

Kønsforskel i resultaterne for de 9-årige

I 9-årsalderen klarer pigerne sig gennemsnitligt bedre end drengene i alle deltagende lande, og dette mønster går igen i samtlige nordiske lande. 
Figuren 1 nedenfor viser forskellen i den absolutte pointscore (udregnet på baggrund af Rasch-scoren) mellem drenge og piger - hvis piger fx scorer 525 point og drenge 475 point i undersøgelsen, vil forskellen være 50 point. Figuren viser at der er den største forskel mellem drenge og piger i Danmark. I Island og Norge klarer pigerne sig også noget bedre end drengene, mens forskellen mellem drenge og piger i Finland og Sverige ligger meget tæt på gennemsnittet for de 27 lande i undersøgelsen (Elley, 1992).

Figur 1: Forskellen i læsefærdigheder mellem 9-årige piger og drenge i IEAundersøgelsen

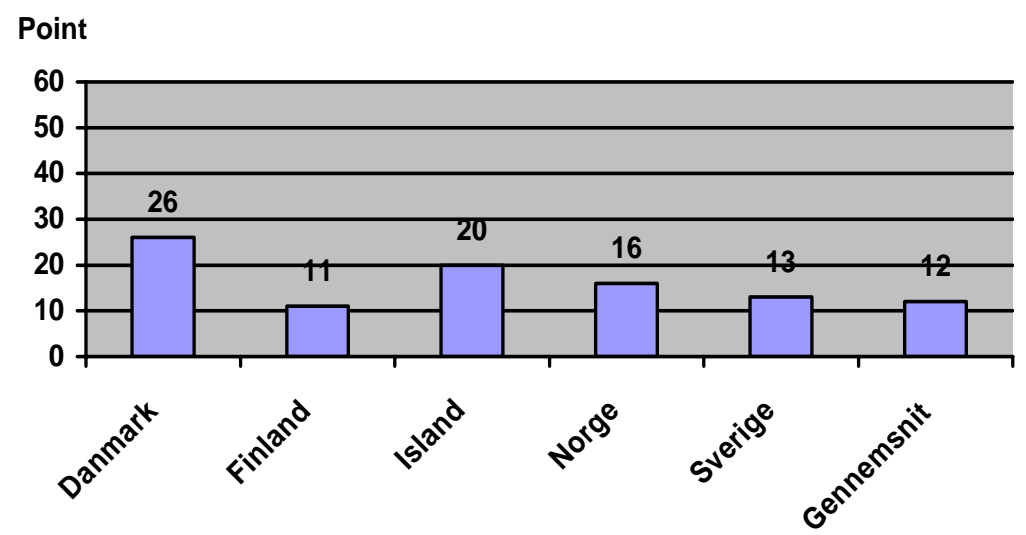

(Kilde: Elley, 1992).

Pigerne er især bedre end drengene til at læse skønlitterære tekster, og de er også væsentlig stærkere inden for de faglitterære tekster, mens drengene klarede sig relativt bedre inden for de skematiserede tekster (Elley, 1992).

Kønsforskel i resultaterne for de 14-årige

I 14-årsalderen er den gennemsnitlige forskel mellem drenge og piger mindre. I Danmark - hvor der for de 9-årige er den største forskel - er forskellen mellem drenge og piger næsten væk. Det samme gælder i Norge. I Island er forskellen mellem drenge og piger en smule mindre end for de 9-årige, mens forskellen i Finland og Sverige for de 14-årige er større end for de 9-årige og langt større end gennemsnittet (Elley, 1992). 
Figur 2: Forskellen i læsefærdigheder mellem 14-årige piger og drenge i IEAundersøgelsen

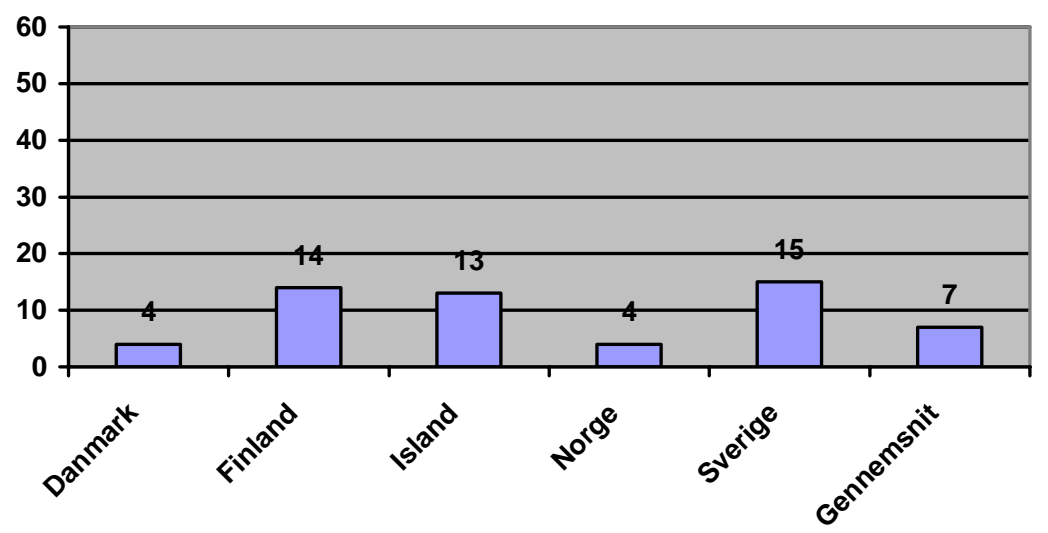

(Kilde: Elley, 1992).

Der er nogle af de samme mønstre for forskelle mellem de forskellige teksttyper for de 14-årige som findes hos de 9-årige. Pigerne er stadig bedre til at læse skønlitterære tekster end drengene, mens drengene har det bedst med de skematiserede tekster (Elley, 1992; Mejding, 1994).

\subsection{PIRLS 2001}

PIRLS-undersøgelsen (Progress in International Reading Literacy Study) blev iværksat som opfølgning på den oprindelige IEA-undersøgelse ti år efter den blev afsluttet i 2001. PIRLS-undersøgelsen blev gennemført i 35 lande, og blandt de nordiske lande deltog Island, Norge og Sverige.

\section{Testmaterialet fra PIRLS}

Undersøgelsen tester 10-åriges læsefærdigheder i forhold til at læse skønlitterære og faglitterære tekster. Undersøgelsen målet de 10-åriges læsefærdigheder på fire områder:

- hente information

- drage simple konklusioner

- tolke og sammenligne information 
- $\quad$ vurdere sprog, indhold og virkemidler i teksten.

PIRLS-undersøgelsen består ud over læsetesten også af fire spørgeskemaundersøgelser til henholdsvis elever, forældre/værge, lærere og skoleledere. Disse undersøgelser handler blandt andet om holdning til at læse, læseundervisning og skolens rammer.

De nordiske landes prcestationer i PIRLS

De svenske skoleelever klarer læsetesten bedst af samtlige deltagende lande. Island ligger over gennemsnittet, mens Norge ligger lige under. Blandt de nordiske lande har Norge også en større spredning i læsefærdighederne, mens spredningen er mindst i Sverige. Det betyder at der ikke er så store forskelle i læsefærdighederne mellem de bedste og dårligste elever i Sverige, som der er blandt de norske elever (Solheim mfl., 2003a og 2003c; Mullis mfl., 2003a).

\section{Kønsforskelle i resultaterne}

I alle de deltagende lande læser pigerne bedre end drengene. Forskellene på drenges og pigers præstationer er, som det fremgår af figur 3, meget lige i de nordiske lande. Det land i undersøgelsen hvor forskellen er mindst, er Italien.

Figur 3: Forskellen i læsefærdigheder mellem piger og drenge i PIRLSundersøgelsen

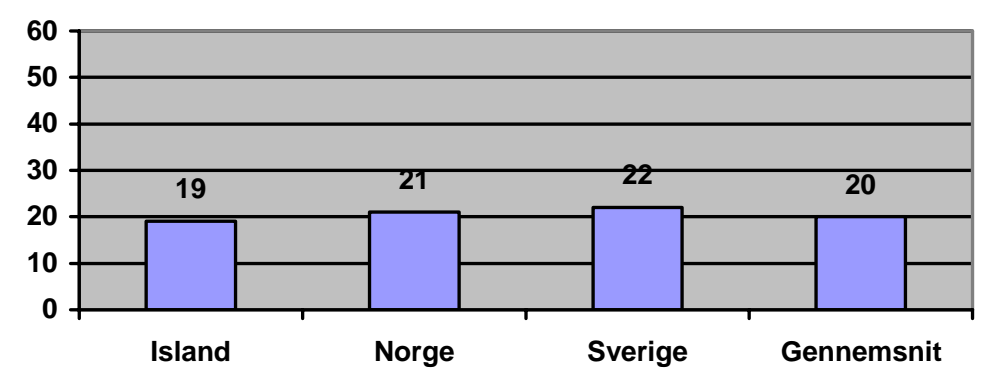

(Kilde: Mullis m.fl, 2003a). 
Testen afprøver, som tidligere nævnt, elevernes læsefærdigheder i forhold til to typer tekster, skønlitterære og faglitterære tekster. I alle de deltagende lande er pigerne bedre end drengene til at læse begge teksttyper. De internationale gennemsnit viser også at forskellen er lige stor ved de to typer. Her adskiller de nordiske lande sig dog ved at forskellen er størst ved de skønlitterære tekster, mens den er mindre ved de faglitterære tekster. I Sverige er drengene bedre til at læse fag- end skønlitterære tekster og det betyder at afstanden til pigernes læsefærdigheder ved faglitterære tekster bliver mindre. I Norge og Island skyldes den mindre kønsforskel i læseresultaterne ved de faglitterære tekster at pigerne er mindre gode til at læse faglitterære end skønlitterære tekster (Solheim mfl., 2003a og 2003c; Mullis mfl., 2003a).

\subsection{Trendstudiet: Fra IEA 1991 til PIRLS 2001}

Ni lande (deriblandt Island og Sverige) valgte i forbindelse med PIRLS 2001 at gennemføre et trendstudie, som er en undersøgelse af udviklingen i læsefærdigheder over en periode på ti år, på baggrund af IEAundersøgelsen fra 1991. Trendstudiet som genbruger den samme læsetest og spørgeskemaundersøgelse fra 1991, er gennemført for at undersøge læseniveauet ti år senere. Island har klaret testen i 2001 bedre end Sverige og kan også registrere en fremgang i læsefærdigheden hvorimod det er gået tilbage for de svenske elever.

I trendstudiet har man også anvendt tre typer af tekster: skønlitterære tekster, faglitterære tekster og skematiserede tekster. De islandske elever klarer sig bedre ved alle tre typer af tekster i 2001, mens svenske elever har klaret sig dårligere, dog er den negative forskel fra 1991 til 2001 for de svenske elever $\mathrm{i}$ at læse skematiserede tekster ikke signifikant.

Resultaterne i trendstudiet er også opgjort for drenge og piger. I Sverige er læsefærdighederne forringet hos både drenge og piger fra 1991 til 2001. Island har oplevet bedre læseresultater for både drenge og piger, men drengenes er øget mere end pigernes. Drengenes øgede læsefærdigheder kan forklare hvorfor Island har opnået et bedre samlet læseresultat i 2001 end i 1991 (Mullis mfl., 2003b). 


\subsection{PISA 2000}

Den første af OECD’s i alt tre PISA-undersøgelser kom i 2000. Formålet med undersøgelsen er at afdække hvor godt unge mennesker er kvalificeret til at møde informationssamfundets udfordringer. Det belyses ved at undersøgelsen måler elevernes færdigheder inden for læsning, matematik og naturfag - i PISA 2000 er der desuden særligt fokus på læsning. Undersøgelsen er gennemført i 32 lande, og fra hvert land deltog typisk 4500 repræsentativt udvalgte 15-årige elever (Andersen mfl., 2001).

\section{Testmaterialet fra PISA}

De tekster og opgaver som er brugt i testmaterialet, er klassificeret ud fra en række forskellige kategorier. I det følgende vil denne klassificering blive gennemgået.

Teksterne er kategoriseret efter struktur, type og læsekontekst. Inden for kategorien struktur er teksterne delt op i kontinuerlige og ikkekontinuerlige tekster:

- Sammenhcengende tekster er udformet i sætninger og afsnit som typisk skal læses fra ende til anden. Disse tekster er delt ind i en række forskellige typer tekster: argumenterende, beskrivende, redegørende, påbydende og fortællende.

- $\quad$ Skematiserede tekster er defineret ved struktur frem for indhold og kan være udformet som grafer, formler, kort, skemaer og tabeller.

Teksterne er også klassificeret efter kontekst, dvs. hvilken situation de læses i. Der er fire læsekontekster: uddannelsesmæssig, arbejdsmæssig, personlig og offentlig. Det at læse et brev vil typisk foregå i en personlig kontekst, mens læsning af en togplan som regel vil finde sted i en offentlig kontekst.

Opgaverne er kategoriseret efter hvilke færdigheder de søger at afdække. Ud fra en færdighedsskala er opgaverne derfor inddelt i tre kategorier: indhentning af information, fortolkning og refleksion. Svarformaterne er koblet til inddeling efter færdigheder og består af tre typer: faste svarmuligheder, korte svar og åbne svarmuligheder (Lie mfl., 2003). 
Der er en vis sammenhængen mellem hvilken færdighed en opgave forsøger at afdække, og svarformatet - fx vil en opgave der søger at afdække hvorvidt en elev kan reflektere over en tekst, ofte have åbne svarmuligheder.

\section{De nordiske landes prestationer}

I PISA 2000 placerer de nordiske lande sig enten over eller omkring OECD-gennemsnittet. Finland placerer sig igen helt i top, mens Sverige og Island placerer sig over OECD-gennemsnittet. Både Danmark og Norge placerer sig omkring gennemsnittet (Andersen mfl., 2001).

\section{Gode og dårlige lcesere}

I PISA-undersøgelserne opgøres læseresultaterne i fem niveauer som gør det muligt på en overskuelig måde at se hvordan elevernes læsefærdigheder er fordelt.

Til niveau 5 hører eleverne med de bedste læsefærdigheder (herefter kaldt gode læsere) og til niveau 1 hører elever uden funktionel læsekompetence (herefter kaldt dårlige læsere). Eleverne på niveau 1 har så ringe læsefærdigheder at de med stor sandsynlighed vil have svært ved at leve op til de krav som stilles i det videre uddannelsessystem og i det moderne samfund generelt. Det er særligt størrelsen på sidstnævnte gruppe som er vigtig at få identificeret.

I PISA 2000 har Finland langt den største andel af gode læsere. Herefter kommer en gruppe med Sverige, Norge og Island hvor andelen af gode læsere er omkring samme størrelse. Endelig har Danmark i PISA 2000 færrest gode læsere af de nordiske lande. Samtidig har Danmark og Norge flest dårlige læsere, Sverige og Island har lidt færre, og endelig har Finland den mindste gruppe af dårlige læsere (Andersen mfl., 2001).

\section{Kønsforskel i resultater}

I samtlige nordiske lande klarer pigerne sig markant bedre end drengene. Forskellen er klart størst i Finland, mens den mindste forskel findes i Danmark. Den mindre forskel i Danmark mellem drenge og piger skyldes at de danske piger ikke læser så godt som pigerne i de andre lande. 
Figur 4: Forskellen i læsefærdigheder mellem piger og drenge i PISA 2000undersøgelsen

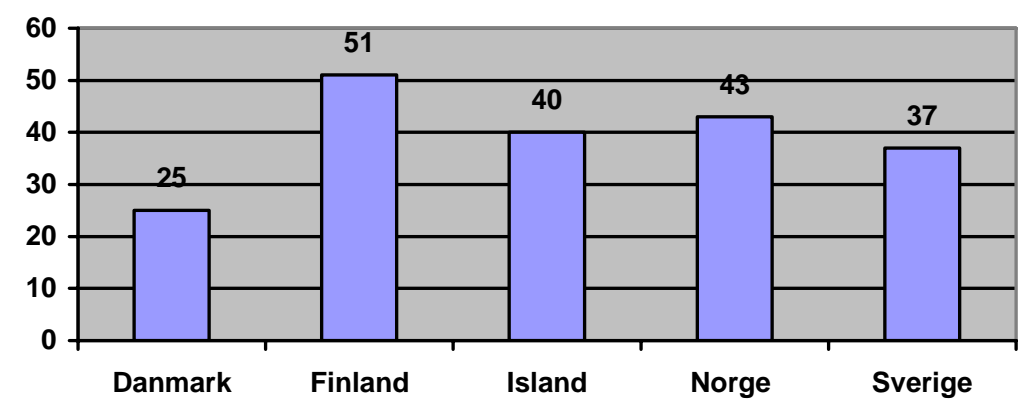

(Kilde: Andersen mfl., 2001)

I forhold til de gennemgåede klassifikationer tegner der sig nogle tydelige mønstre i undersøgelsesmaterialet. Pigerne er generelt bedre end drengene til at læse sammenhængende tekster, de er især gode til at læse fortællende, påbydende og argumenterende tekster, mens kønsforskellen er mindre for de redegørende og især de beskrivende tekster.

På samme måde er der en sammenhæng mellem drenges og pigers præstationer afhængig af læsekonteksten. Pigerne er bedre til at læse tekster som relaterer sig til en arbejdsmæssig kontekst og sekundært til en personlig kontekst. Drengene klarer sig derimod næsten lige så godt som pigerne i tekster der er forbundet med en offentlig læsekontekst.

Det har også stor betydning hvilken færdighed den enkelte opgave prøver at afdække. Drengene er relativt bedre til at indhente information fra en tekst, mens pigerne klarer sig bedre når det gælder om at fortolke og især reflektere over tekster. Som tidligere påpeget har dette en kobling til forskellige svarformater, og det viser sig at drenge klarer sig bedre inden for opgaver med faste svarmuligheder, mens piger er langt stærkere end drengene i opgaver hvor de skal svare og formulere sig frit (Lie mfl., 2003).

I forhold til elevernes placering i de fem niveauer af læsere er det værd at bemærke at drenge udgør den største andel blandt de dårlige læsere på niveau $1 \mathrm{i}$ alle nordiske lande (Andersen mfl., 2001). 


\subsection{PISA 2003}

PISA 2003 blev gennemført som den anden del af de tre PISAundersøgelser (den sidste udkommer i 2006). I undersøgelsen deltog denne gang 41 lande - herunder samtlige nordiske lande - og som i PISA 2000 deltog fra hvert land omkring 4500 repræsentativt udvalgte 15-16årige elever.

PISA 2003 undersøger ligeledes elevernes færdigheder inden for læsning, matematik og naturfag, men hvor PISA 2000 havde særligt fokus på læsning, fokuserer PISA 2003 særligt på matematik. Derfor valgte man i PISA 2003 kun at anvende en begrænset del af den omfattende læsetest i PISA 2000. Det betyder at det ikke har været muligt at opdele testresultaterne i forhold til de klassificeringer som er gennemgået i det ovenstående i forbindelse med PISA 2000.

\section{De nordiske landes prcestationer}

I PISA 2003 har Finland igen de bedste læseresultater af samtlige deltagende lande i undersøgelsen, og også Sverige placerer sig markant over OECD-gennemsnittet. Norge ligger lige over gennemsnittet, mens Island og Danmark placerer sig lige under (Mejding, 2004).

Sammenlignet med PISA 2000 er det kun de islandske elever der har præsteret signifikant dårligere ved læsetesten i 2003. I Danmark, Norge, Sverige og Finland er der ingen signifikante forskelle i resultaterne.

\section{Gode og dårlige lcesere}

I PISA 2003 har Finland og Sverige langt flere gode læsere end Danmark, Norge og Island. Samtidig har Finland den absolut mindste andel af dårlige læsere, mens denne andel er lidt større i Sverige og størst i Island, Norge, og Danmark der har nogenlunde samme andel af dårlige læsere (Mejding, 2004).

\section{Kønsforskel i resultater}

I alle de deltagende lande læser pigerne bedre end drengene. I de nordiske lande er kønsforskellen størst i Island og mindst i Danmark. Igen skyldes 
den mindre forskel i Danmark at de danske piger læser dårligere end pigerne i de øvrige nordiske lande, og ikke at danske drenge læser bedre end drengene i de øvrige nordiske lande.

Figur 5: Forskellen i læsefærdigheder mellem 9-årige piger og drenge i PISA 2003-undersøgelsen

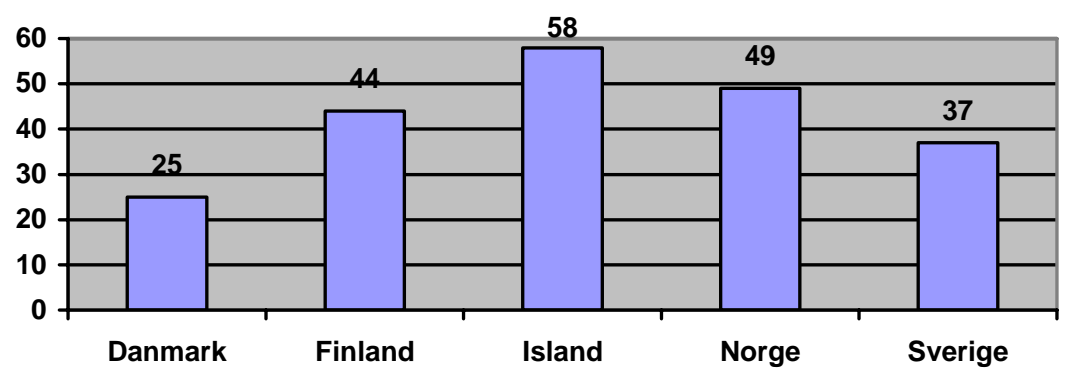

(Kilde: Mejding, 2004)

\subsection{Forskelle i prøvematerialet fra IEA til PISA}

I begyndelsen af kapitlet tog vi forbehold over for at sammenligne testresultater fra de forskellige undersøgelser fordi prøvematerialet er forskelligt. Det er dog ud fra gennemgangen tydeligt at kønsforskellen er væsentlig større i PISA-undersøgelserne end i IEA-undersøgelserne. Dette afsnit vil se nærmere på hvordan testmaterialet kan påvirke forskellen mellem drenges og pigers præstationer.

Prøvematerialet for PISA 2000 og PISA 2003 er det samme, mens prøvematerialet for IEA- og PIRLS-undersøgelserne - som begge er foretaget af IEA - ganske vist er forskelligt, men opbygget efter samme skabelon med hensyn til blandt andet teksttyper.

Et bud på hvorfor visse tekster er nemmere for piger at læse, mens andre er nemmere for drenge at læse, handler om opfattelsen af tekster. Når læseren afkoder en tekst, vil han eller hun gøre brug af en række forud dannede skemaer hvorigennem det læste kommer til at give mening. Der er derfor tale om at hver enkelt læser har en række forståelsesskemaer som er afgørende for hvad der i en læseproces giver mening. Dermed vil nogle tekster give god mening for nogle læsere, mens de for andre læsere vil være sværere at forstå (Lie mfl. 2003; Elbro, 2001). 
Disse forståelsesskemaer vil på nogle punkter være forskellige for drenge og piger, og derfor vil nogle teksttyper generelt give bedre mening for piger end for drenge. En mulig årsag til at der er større forskel mellem drengenes og pigernes præstationer i PISA-undersøgelserne end i undersøgelserne foretaget af IEA, kan derfor være at testmaterialet for PISAundersøgelsen i højere grad er foreneligt med pigernes forståelsesrammer end testmaterialet fra IEA (Lie mfl., 2003).

\section{Litteratur:}

Andersen mfl. (2001): Forventninger og færdigheder - danske unge i en international sammenligning, AKF, DPU og SFI; Danmark

Elbro, Carsten (2001): Læsning og læseundervisning, Gyldendal, Danmark

Elley, W.B. (1992): How in the world do students read?, IEA; Tyskland

Lie mfl. (2003): Northern Lights on PISA, University of Oslo, Norge

Mejding, Jan (1994): Den grimme ælling og svanerne, DPI; Danmark

Mejding, Jan (2004): PISA 2003 - danske unge i en international sammenligning, DPU, Danmark
Mullis mfl. (2003a): PIRLS 2001 International Report, Boston College; USA Mullis mfl. (2003b): PIRLS trends in Childrens Reading Literacy Achievement 1991-2001, Boston College; USA

Solheim mfl. (2003a): En norsk kortversjon av den internasjonale rapporten om 10-åringers lesekunnskaper, Senter for leseforsking; Norge

Solheim mfl. (2003c): Slik leser 10åringer i Norge, Senter for leseforsking, Norge 


\section{Systemniveau}

Børn og unges læsefærdigheder afhænger også af en række faktorer som ikke direkte er knyttet til elever eller skoler. Dette kapitel fremhæver de faktorer på systemniveau der har indflydelse på læsefærdighederne. Kapitlet fokuserer på to dele: elevernes socioøkonomiske og demografiske baggrund og udviklingsarbejde med læsning i grundskolen. Der er også en række andre faktorer der kan tillægges en betydning, men det vil være uden for rapportens sigte at kortlægge alle disse (se også afgrænsning i kapitel 2).

Kapitlet inddrager de internationale undersøgelser der er præsenteret i kapitel 3. Desuden inddrages nationale og mindre nordiske undersøgelser som baggrund for at identificere hvilke årsager der er til resultaterne i undersøgelserne.

Første del af kapitlet behandler de socioøkonomiske forhold som $\mathrm{fx}$ forældrenes uddannelse og økonomi, elevernes modersmål og om eleverne kommer fra landdistrikter eller byer. Denne del danner baggrund for behandlingen af elevniveauet i kapitel 6 .

Anden del af kapitlet fokuserer på udviklingsarbejdet med læsning som både omfatter centrale prioriteringer på forskningsområdet samt initiativer - herunder også lokale - der sigter på at forankre forskningsresultater på skoleniveau. Denne del er knyttet til skoleniveauet som behandles i kapitel 5.

\subsection{Socioøkonomiske forhold}

En analyse på tværs af resultaterne fra PISA 2000 og 2003 og fra PIRLS viser at elevernes socioøkonomiske baggrund har stor betydning for deres præstationer i læsetestene. (Danmarks Teknologiske Institut, 2005). 
I elevernes socioøkonomiske baggrund er der fire faktorer som vil blive behandlet særskilt i dette kapitel. Det er:

- forældrenes uddannelsesmæssige baggrund

- forældrenes økonomiske ressourcer

- forældrenes kulturelle ressourcer

- elevernes modersmål.

\subsubsection{Forceldrenes uddannelsesmassige baggrund}

PIRLS viser at forældrenes uddannelsesniveau har positiv betydning for elevernes læsepræstation. Det betyder at elever, hvor forældrene har en videregående uddannelse gennemsnitligt læser bedre end elever, hvor forældrene ingen uddannelse har udover grundskolen. Desuden viser undersøgelsen at forældrene i de nordiske lande har et højt uddannelsesniveau sammenlignet med øvrige lande. (Mullis mfl., 2003a).

For de norske elever har det især betydning hvis moderen har en høj uddannelse. Forældrenes arbejde er naturligvis knyttet til deres uddannelsesbaggrund, og der kan også her ses en sammenhæng med elevernes læsefærdigheder. I Sverige er andelen af forældre, specielt mødre, med en embedsmandsansættelse højere end andre lande, og det har også positiv betydning for elevernes læsefærdigheder (Skolverket, 2003b; Solheim, 2003a og 2003c).

Ifølge den danske læseundersøgelse Folkeskolen år 2000 (herefter F2000), der gentager dele af IEA-læseundersøgelsen fra 1991, er der også i Danmark en tydelig sammenhæng mellem forældrenes uddannelse og elevernes præstationer i læseprøverne. Også i Danmark er det især mødrenes uddannelse der har indflydelse på elevernes læsefærdigheder (Allerup, 2001).

I PISA 2000 er forældrenes socioøkonomiske status defineret som forældrenes erhvervsmæssige status. Resultaterne viser at der er sammenhæng mellem den socioøkonomiske status og elevernes læsefærdigheder. PISA 2000 viser at sammenhængen i OECD-landene er mindst i Korea, Finland og Island og de øvrige nordiske lande. Sverige, Norge og Danmark ligger også alle under OECD-gennemsnittet selv om forskellen her er større. De største forskelle i OECD-sammenhæng findes i fx Tyskland, Schweiz og Luxembourg (Välijärvi, 2002a; Kirsch, 2002). 
En analyse af Finlands resultater viser at selv om gruppen af elever med den laveste socioøkonomiske baggrund, læser dårligere end eleverne med bedre socioøkonomisk baggrund, så har gruppen et læseniveau der er højere end gennemsnittet i de øvrige lande i PISA 2000-undersøgelsen (Välijärvi mfl., 2002a). PISA-undersøgelsen viser desuden at en af årsagerne til at de finske elever er de bedste læsere, er at Finland har været bedre til at bryde elevernes socioøkonomiske arv (Välijärvi mfl., 2002b).

Norske analyser af PISA 2000-resultaterne viser at der i Norge er en stærkere sammenhæng mellem den socioøkonomiske status og med pigernes læsefærdigheder end med drengenes færdigheder (Lie mfl., 2001; Kjærnsli, 2004). De norske analyser forklarer ikke hvorfor forældrenes uddannelsesmæssige og kulturelle status har større betydning for pigerne end for drengene.

\subsubsection{Forceldrenes økonomiske ressourcer}

I IEA-undersøgelsen blev eleverne bedt om at besvare nogle spørgsmål om deres forældres økonomiske baggrund målt i forhold til materielle goder. Forundersøgelsen viste at de 9-årige havde svært ved at besvare spørgsmålene, og det er derfor kun de 14-årige der besvarede den del af spørgeskemaet i den endelige undersøgelse. Elevernes svar viser at der er en svag sammenhæng mellem forældrenes og dermed familiens økonomiske ressourcer og elevernes læsefærdigheder. Analysen viser også at betydningen af forældrenes uddannelse for elevernes præstation er større (Taube, 1995).

\subsubsection{Forceldrenes kulturelle ressourcer}

Forældrenes kulturelle ressourcer er en samlet betegnelse for forældrenes pædagogiske ressourcer og kulturelle interesser. Betegnelsen pædagogiske ressourcer er benyttet i læseundersøgelserne og omfatter materielle genstande som antal bøger og børnebøger i hjemmet og om eleven har sit eget skrivebord og sin egen computer. Kulturelle interesser er fx antal af bøger i hjemmet og kulturelle aktiviteter som at gå i teatret eller på biblioteket. Begge dele har betydning for elevernes læsefærdigheder. 


\section{Pcedagogiske ressourcer}

PIRLS 2001-testen har samlet følgende faktorer til et indeks med betegnelsen pædagogiske ressourcer i hjemmet: antal bøger og børnebøger i hjemmet, egen pc og eget skrivebord, daglig adgang til aviser og forældrenes uddannelse. I PIRLS er Norge, Sverige og Island mellem de fem bedst scorende lande, dvs. blandt de lande hvor eleverne har den højeste score på pædagogiske ressourcer i hjemmet. Resultaterne viser en tydelig positiv sammenhæng mellem mange pædagogiske ressourcer i hjemmet og gode læsefærdigheder (Solheim, 2003a og 2003c; Mullis mfl., 2003a).

I PISA 2000 dækker pædagogiske ressourcer over det at eleven har ordbøger, lommeregner, et skrivebord, en rolig plads til at lave lektier og læsebøger derhjemme. Resultaterne af PISA 2000 viser som PIRLSundersøgelsen at der er en sammenhæng mellem pædagogiske ressourcer og læsefærdigheder. Elever fra hjem med pædagogiske ressourcer vil i gennemsnit klare læsetesten bedre end elever uden (Kirsch mfl., 2002).

\section{Kulturelle interesser}

Et af de forhold der siger noget om forældrenes kulturelle interesser, er antallet af bøget $\mathrm{i}$ hjemmet og deres holdning til at læse. IEAundersøgelsen viser at der er en klar positiv sammenhæng mellem mange bøger i hjemmet og elevens læsefærdigheder (Elley, 1992).

Sammenhængen mellem antallet af bøger i hjemmet og elevernes lyst til at læse i fritiden er også undersøgt. I syv lande, heriblandt Sverige, er der en stærk sammenhæng. Det vil sige at elever fra hjem med mange bøger læser mere end elever fra hjem med få bøger. I fem lande, blandt andet Danmark, er der ingen sammenhæng med antallet af bøger. Det er kendetegnende for de fem lande at eleverne har god adgang til bøger i andre fora på skolen eller biblioteket, og at de anvender biblioteket (Elley, 1992).

PISA-undersøgelsen viser i 2000 at elever fra hjem med mange bøger har et større læseengagement og læser bedre end elever fra hjem med færre bøger. PIRLS 2001 viser en lignende sammenhæng mellem antal bøger i hjemmet og læsefærdigheder (Mullis mfl., 2003a). Resultaterne kan blandt andet forklares ved at bøger i hjemmet giver børnene opfattelsen af at bøger og læsning værdsættes af forældrene(Skolverket, 2003b). 
Når det gælder antallet af bøger, skiller de nordiske lande sig positivt ud i forhold til gennemsnittet i PIRLS-undersøgelsen da mellem 23-31 \% (Sverige har den højeste andel) af eleverne har angivet at der er over 200 bøger i hjemmet. Det internationale gennemsnit er 15 \% (Mullis mfl., 2003a).

PIRLS 2001 viser at der er en klar sammenhæng mellem elevernes læsefærdigheder og forældrenes holdning til læsning. Forældrenes holdning til at læse er belyst gennem et indeks bygget på fem udsagn omkring læsning. Elever med forældre med positiv holdning til at læse klarer sig bedst i læsetesten. (Solheim, 2003a og 2003 b). Forældrene i Sverige, Norge og Island er meget positive over for læsning og ligger blandt de seks mest positive af de 35 deltagende lande (Mullis, 2003a).

I Nordlæs-undersøgelsen ${ }^{2}$ ser svenske og finske forældre læsning som en måde at bevare kulturarven på og mener at samfundet forventer at børn læser visse bøger. For de svenske og finske forældre er det vigtigt at støtte barnet når det vil lære at anvende skriftsprog. Svenske og finske forældre svarer derfor ofte på barnets spørgsmål om ord og bogstaver, og flere af de svenske og finske børn kunne skrive ord inden de kom i skole. Mange hjem havde derfor et fællesskab omkring læsning og skrivning hvilket samtidig skabte en forventning til børnenes færdigheder når de kom i skole (Sommer, 1996).

Et andet forhold der gør sig gældende i forhold til elevernes holdning til at læse og deres læsefærdigheder, er forældrenes lyst til at tale om bøger og andre kulturelle interesser med børnene. I PISA 2000 har man undersøgt hvor ofte eleverne oplever at de taler med deres forældre om sociale og politiske emner, bøger, film eller tv og lytter til klassisk musik med dem. Svarene fra eleverne er samlet i et indeks betegnet kulturel kommunikation, og analysen viser at der er en klar sammenhæng mellem forældrenes kulturelle kommunikation med børnene og deres læsefærdigheder og læseengagement (Kirsch, 2002).

\footnotetext{
${ }^{2}$ Nordlæs-undersøgelsen er foretaget af det danske Undervisningsministerium og det daværende Danmarks Pædagogiske Institut (i dag Danmarks Pædagogiske Universitet). Læse-prøven er den samme som blev anvendt ved IEA-undersøgelsen i 1991, og blev gennemført i 1995. Ud over Danmark medvirker svenske og finske børn i undersøgelsen - de finske børn er delt op i en svensk og en finsktalende gruppe. De svensktalende finske børn klarede sig generelt bedst i undersøgelse. Herefter kom de svenske og finsktalende finske børn der scorede næsten lige meget, mens de danske børn klarede sig dårligst (Sommer et al 1996).
} 
Den danske læseundersøgelse F2000 inddrager forældrenes kulturelle aktiviteter, $\mathrm{fx}$ at gå i teatret eller på biblioteket, som parameter i tolkningen af læseresultaterne. Undersøgelsen viser at børn hvis forældre dels selv læser bøger og går i teatret, dels inddrager børnene i kulturelle aktiviteter, er bedre læsere (Allerup, 2001).

\subsubsection{Elever med andet modersmål}

En problemstilling der også er tilknyttet socioøkonomisk baggrund og læsefærdigheder, er hvordan elever med indvandrerbaggrund klarer sig. PIRLS-læseundersøgelsen viser at der er en klar sammenhæng mellem elevernes læsefærdighed og hvor ofte sproget i undersøgelsen tales af eleven derhjemme. I de nordiske lande taler mindst $88 \%$ af eleverne testsproget altid eller næsten altid derhjemme. De elever der taler testsproget mindre hyppigt hjemme, klarer sig dårligere i testen (Mullis, 2003a).

Et andet parameter for elevernes baggrund er forældrenes oprindelsesland. I PIRLS er sammenhængen mellem om forældrene er født i testlandet, og elevernes præstation derfor undersøgt. I 22 lande, heriblandt Sverige og Norge, har elever med begge forældre født i det pågældende land et bedre læseresultat end elever hvor begge forældre er født $\mathrm{i}$ et andet land. Sammenhængen kan ikke undersøges i Island fordi der mangler oplysninger. Norge har den største forskel i læsefærdighed, mens Sverige ligger på en delt fjerdeplads sammen med Holland (Mullis, 2003a).

I Norge har Åsa K H Wagner lavet en analyse af de norske PIRLSresultater. Analysen viser at blandt de164 elever med indvandrerbaggrund læser pigerne bedre end drengene (resultatet er ikke signifikant pga. det lille udsnit) (Wagner, 2004).

En svensk analyse af PISA 2000-læseresultaterne for elever med indvandrerbaggrund viser det samme mønster. Elever med indvandrerbaggrund klarer sig dårligere end deres indfødte skolekammerater, dvs. elever hvis forældre begge er født i testlandet, og der er den samme kønsforskel i gruppen af elever med indvandrerbaggrund til pigernes fordel (Skolverket, 2003a). Forskellen mellem drenge og piger har fået en ekstra dimension i Sverige da opgørelser over afgangskarakterer efter grundskolen har vist at piger med indvandrerbaggrund i 1999 og 2004 afsluttede 
med et bedre gennemsnit end drenge med en svensk baggrund (Skolverket 2005).

Den norske analyse af PISA 2000 og 2003 viser også at elever der taler et andet sprog derhjemme, klarer læsetesten dårligere end de øvrige norske elever. Analysen viser endvidere at eleverne fra hjem der taler et andet sprog end norsk, har færre socioøkonomiske og kulturelle ressourcer hjemme end de øvrige norske elever. Forskellen mellem de to grupper af elever kan dermed både skyldes et andet sprog i hjemmet og deres socioøkonomiske status (Kjærnsli, 2004). Det er, sammenholdt med indvandrerpigernes gode afgangskarakterer i Sverige, tankevækkende og bør give anledning til overvejelser om hvordan indvandrerelevernes sociale barrierer brydes, og hvordan drenge generelt motiveres til uddannelse.

\subsubsection{D emografiske forhold}

IEA-undersøgelsen viser at i Danmark klarer børn fra de større byer sig en smule bedre end børn fra mindre byer og fra landet. I Sverige er det omvendt - her klarer børn fra mindre byer og landet sig bedre end børn fra større byer. I Finland er der ingen synlige forskelle mellem by og land (Elley, 1992).

I PIRLS 2001 har skolelederne svaret på hvor skolerne er placeret geografisk i byer, forstæder eller landdistrikter. I Island klarer eleverne fra byerne læsetesten bedre end elever fra forstæder, der har bedre læsefærdigheder end elever fra landdistrikter. I Norge er mere end halvdelen (56\%) af eleverne ifølge skolelederen bosat i landdistrikter, og det er elever herfra der har de ringeste læsefærdigheder, mens eleverne fra forstæderne klarer sig bedst. Ifølge de svenske skoleledere er to tredjedele af eleverne bosat i forstæderne, og læsetesten viser at disse elever sammen med elever fra landdistrikter klarer testen dårligst, og elever fra byerne klarer den bedst. (Mullis, 2003a).

Den finske opgørelse af PISA 2000 viser at det har større betydning for drenges læsefærdigheder end for pigers at bo på landet. Drenge der går i landsbyskoler, klarer læsetesten dårligere end drenge fra byskoler i alle dele af Finland. Pigernes læsefærdigheder i alle dele af Finland er relativt uafhængig af om pigerne går i by- eller landsbyskole (Välijärvi, 2002a). 
Tendensen til at elever fra byer eller forstæder er de bedste læsere, bør ses i sammenhæng med at forældre med høj uddannelse oftest bosætter sig og har arbejde i eller omkring byerne. Uddannelsesniveauet i landdistrikterne er derfor lavere. Den finske analyse af PISA 2000 viser dog at køn også har betydning for læsefærdighederne i landdistrikterne. En af grundene til at drengene fra landsbyskolerne ikke klarer læsetesten så godt som drenge fra byskoler, kan være at drengene fra landet har et liv hvor deres identitet afhænger mere af fx naturoplevelser (som jagt og fiskeri) end af uddannelse og læsning.

\section{Fokusområde for fremtidige undersøgelser}

Forældrenes socioøkonomiske baggrund har stor betydning for deres børns præstationer i uddannelse og deres læsefærdigheder - også i de nordiske lande.

Befolkningerne i de fem nordiske lande har en relativt ens socioøkonomisk status. Resultaterne i kapitel 3 og analyserne ovenfor viser imidlertid at niveauet for elevernes læsefærdigheder varierer i de nordiske lande. De finske elever klarer sig markant bedre end de andre, og dermed er det lykkedes Finland at give eleverne med den svageste baggrund gode læsefærdigheder.

I en fremtidig undersøgelse vil det være relevant at afdække hvorfor socioøkonomiske barrierer brydes bedre i fx Finland end i de øvrige lande. Det vil også være relevant fordi formålet med grundskolen i de nordiske lande er at udligne socioøkonomiske forskelle. Det vil derfor også være aktuelt at undersøge hvilken betydning socioøkonomisk status har for læsefærdighederne i de nordiske lande, hvordan skolerne tager højde for elevernes baggrund, og hvilken betydning den socioøkonomiske baggrund har for henholdsvis piger og drenge.

\subsection{Udviklingsarbejde med læsning}

Læseområdet afhænger af en række strukturelle forhold i de nationale uddannelsessystemer. Da det er uden for denne rapports sigte at redegøre dybdegående for samtlige forhold, vil vi i stedet slå ned på de enkelte forhold som er relevante for at udvikle læsning i de nationale uddannelsessystemer. Læreruddannelsen bliver kortlagt i en separat rapport fra Nordisk Ministerråd og behandles derfor ikke her. 


\subsubsection{Forskning og forankring på skoleniveau}

Der er flere aspekter i forskningens rolle i forbindelse med læsefærdigheder.

For det første er der spørgsmålet om hvorvidt man politisk vil prioritere forskning i læsning. Der er store forskelle på hvor meget der bliver forsket i læsning i de nordiske lande. Norge har ved Universitetet i Stavanger et center for læseforskning og læseoplæring med flere fastansatte og dermed et forskningsmiljø, mens fx Danmark har langt færre forskere inden for læsning, og de er spredt på flere universiteter (Mandag Morgen, 2004). Finland har heller ikke et samlet læsecenter som i Norge, men enheder på flere af universiteterne der forsker i læsning og læsefærdigheder.

Et andet aspekt i forskningens rolle i forbindelse med læsefærdigheder er at den viden som stammer fra forskningen, skal bringes i spil i den enkelte kommune og på skolerne. En evaluering som EVA har gennemført, viser at udbyttet af udviklingsprojekter bliver større hvis skolerne og lærerne samarbejder med faglige eksperter som forsker i læsning og didaktik. Projekterne fører til en dybere refleksion over praksis i kommunen og på skolen, og viden fra forskningen bliver i højere grad brugt i hverdagen (EVA, 2005c).

Den såkaldte Chicago-model som blev indført i slutningen af 80'erne for at omstrukturere et miserabelt skolesystem i Chicago, tilstræber på et konkret plan at få forskning til at fungere som en del af udviklingen på skolen og i undervisningen. Ved at bruge forskningen som en del af skoleudviklingen var skolerne i stand til løbende at identificere hvilke faktorer som reelt havde betydning for udvikling (EVA, 2003).

I Danmark har læseudvalget, som er et udvalg der forbereder en national handleplan for læsning, netop anbefalet at satse mere på forskning $\mathrm{i}$ forbindelse med en samlet indsats på læseområdet i Danmark. Udvalget foreslår desuden at undersøge mulighederne for at etablere en nordisk enhed der kan bearbejde og formidle forskningsresultater til pædagoger og lærere (Undervisningsministeriet, 2005).

Samtidig har de danske ministerier på uddannelsesområdet (Ministeriet for Videnskab, Teknologi og Udvikling og Undervisningsministeriet) i samarbejde med EVA og Danmarks Pædagogiske Universitet oprettet et 
såkaldt clearinghouse ${ }^{3}$. Formålet er at følge den pædagogiske forskning nationalt og internationalt og sikre at forskning præsenteres og gøres tilgængelig for forskere og praktikere.

Fokusområde for fremtidige undersøgelser

Erfaringer viser at udbyttet af $\mathrm{fx}$ udviklingsprojekter omkring læsning bliver større hvis viden fra forskningen inddrages. Derfor vil det være relevant at se på hvordan forskning kan forankres bedre på skoleniveau.

Problemerne med at få sat viden fra læseforskningen i spil på de enkelte skoler gælder især international forskning (Mandag Morgen, 2004). Det skyldes sandsynligvis flere ting, herunder at den internationale forskning ikke nødvendigvis bliver drøftet så ofte eller har nationale fortalere, og at forskningen ikke vil kunne tage højde for betingelserne i de enkelte lande. Derfor er der her et potentiale for et nordisk netværk.

De nordiske lande har på trods af forskellige uddannelsessystemer samme udgangspunkt for deres grundskole på afgørende punkter: både formålet med grundskolen og landenes socioøkonomiske udgangspunkt er meget ens. Derfor vil de nordiske lande kunne drage nytte af et forskningsnetværk hvorigennem viden om forskning i Norden kan blive videreformidlet til uddannelsesdebatten i de enkelte lande. Landene vil på den måde få et langt større udbytte af den nordiske og internationale forskning.

Det vil desuden være relevant at supplere forskernetværk med en række netværk som på et mere praktisk niveau (fx læsekonsulenter) vil kunne drage nytte af en større erfaringsudveksling. Netværkene kan være med til at forankre forskningen bedre på skolerne og dermed bidrage med nu viden til udvikling og kvalitetssikring af læseundervisningen.

\footnotetext{
${ }^{3}$ Et clearinghouse er en organisation der indsamler dokumenter, oplysninger og viden inden for et bestemt emneområde eller af en vis type. Disse dokumenter eller oplysninger bearbejdes, og der udsendes dokumenter eller informationer om det indsamlede.
} 


\section{Fokusområde for fremtidige undersøgelser}

Det er især den internationale forskning der ikke inddrages til at udvikle og forbedre undervisningen i læsning. Derfor vil det være relevant at undersøge hvordan de nordiske lande kan blive bedre til at samarbejde i netværk på både forsker- og praksisniveau.

Evalueringer kan også bidrage til at bringe viden om fx god undervisningspraksis i spil på skolerne. En stærk kultur for evaluering kan hjælpe skolerne til at reflektere over deres egen praksis og sikre kvaliteten af deres evalueringer. For at evalueringerne skal være tilstrækkeligt systematiske, er det vigtigt at de har karakter af forløb og ikke er punktnedslag en eller to gange om året (EVA, 2005a).

Specifikt i forhold til at få forskning forankret på skoleniveau kan evalueringer spille en særlig rolle. Ideen med at anvende forskningsresultater i hverdagen handler netop om at give lærerne mulighed for at reflektere og forbedre den eksisterende praksis. Den tidligere nævnte Chicagomodel fokuserer netop på at de evalueringsinstitutioner som omgiver skolen, skal fungere i et tæt samarbejde også med forskningsinstitutioner (EVA, 2003).

\section{Fokusområde for fremtidige undersøgelser}

Da systematiske evalueringer kan være en nyttig måde at ændre eksisterende praksisser, vil det være relevant at undersøge hvordan nordiske netværk kan anvendes til at opbygge en god evalueringskultur på skolerne.

\section{Lokale læeseprojekter}

De overordnede erfaringer fra lokale læseprojekter hvor man har sat særligt fokus på læsning, er at de har en positiv effekt på læsefærdighederne. Det er imidlertid svært at afgøre om den positive effekt skyldes selve projektets indhold eller det at arbejdet med projektet har givet en generel større opmærksomhed på området. 
Mange projekter kan fremhæves, men da formålet med denne rapport ikke er at foretage en kortlægning over nationale udviklingsprojekter, skal der blot omtales nogle få. Et eksempel kan findes i Norge hvor den øgede opmærksomhed i forbindelse med en række kortlægningsøvelser af de yngste skoleelevers læsefærdigheder viste sig at have en positiv effekt på elevernes læsefærdigheder - og især drengene nød godt af opsvinget (Engen, 2005). Andre eksempler er et læseprojekt på Spjelkavik barneskole i Norge og et læseprojekt i Esbjerg Kommune i Danmark der ikke bare så på skolen, men samtidig kiggede på andre skriftsprogsmiljøer i kommunen, $\mathrm{fx}$ folkebiblioteket.

\section{Litteratur:}

Allerup mfl. (2001): Færdigheder i læsning og matematik, Folkeskolen år 2000, Danmark

Danmarks Teknologisk Institut (2005) Explaining Student Performance, DTI, Danmark

Elley, W.B. (1992): How in the world do students read?, IEA, Tyskland

Engen mfl. 2005: Leseferdighet i 2. klasse - våren 2005. Delrapport, Nasjonalt Senter for leseoplæring og leseforskning, Universitet i Stavanger, Norge

EVA (2005a): Fokus på læring, Danmarks Evalueringsinstitut; Danmark

Kirsch mfl. (2002): Reading for change, Performance and engagement across countries, Results from PISA 2000, OECD; Frankrig

Kjærnsli mfl. (2004): Rett spor eller ville veier? Universitetsforlaget, Oslo, Norge

Lie mfl. (2003): Northern Lights on PISA, University of Oslo, Norge

Mandag Morgen (2004): Læseforskning ignoreres i danske skoler, Mandag Morgen nr. 10, 8.3.2004, s. 5-9; Danmark

Mullis mfl. (2003a): PIRLS 2001 International Report, Boston College, USA
Skolverket (2003a): Läsförståelse hos elever med utländsk bakgrund, Skolverket, Rapport 227, Sverige

Skolverket (2003b): Barns läskompetens - i Sverige och i världen (PIRLS 2001), Skolverket, Sverige

Skolverket (2005): Beskrivande data 2005, Skolverket, Sverige

Solheim mfl. (2003a) En norsk kortversjon av den internasjonale rapporten om 10-åringers lesekunnskaper, Senter for leseforsking, Norge

Solheim mfl.(2003c) Slik leser 10åringer i Norge, Senter for leseforsking, Norge

Sommer mfl. (1996): Nordlæs, DPI, Danmark

Taube mfl. (1995): Svensk läsundervisning i ett internationellt perspektiv, Skolverket, Sverige

Undervisningsministeriet (2005): Rapport fra Udvalget til forberedelse af en national handlingsplan for læsning, Undervisningsministeriet, Danmark

Välijärvi mfl. (2002a): Suomen Tulevaisuuden osaajat, University of Jyväskylä, Finland

Välijärvi mfl. (2002b): The Finnish success in PISA - and some reasons behind it, PISA 2000, Institute for 
Educational Research, University of Jyväskylä, Finland

Wagner, Åse K.H. (2004): Hvordan leser minoritetsspråklige elever i Norge?
Nasjonalt senter leseopplæring og leseforskning, Norge 



\section{Skoleniveau}

Forhold på skolen debatteres ofte og ikke uden grund i forbindelse med børns læsefærdigheder. I dette kapitel ser vi nærmere på hvilke faktorer på skoleniveauet som påvirker børns læsning. Til dette formål er skoleniveauet delt op i fire fokusområder: lærerne, læsning i skolen, klassen og forhold på skolen.

Den første del ser specifikt på hvordan lærernes uddannelsesbaggrund og kompetencer kan indvirke på læsefærdigheder og kønsforskellen inden for disse. Anden del ser på hvordan der bliver arbejdet med læsning i skolen - fx typer af læsematerialer, læsetid og arbejdet med det læste. Tredje del ser på hvordan forhold i klassen såsom klassestørrelse og arbejdsmiljø påvirker læsningen. Endelig ser fjerde del på øvrige forhold på skolen - herunder skolens læringsmiljø og skolebiblioteker.

\subsection{Lærerne}

I PISA-undersøgelsen fra 2000 er en positiv lærer-elev-relation den mest betydningsfulde faktor på skoleniveau for elevernes læsepræstationer (Kjærnsli, 2004). Hermed understreger undersøgelsen at lærerne spiller en afgørende rolle i læseundervisningen, og at læseundervisningen spiller en afgørende rolle i forhold til læsefærdighederne. I det følgende vil afsnittet se på lærernes professionalisme, køn og samarbejde, som er væsentlige faktorer for en positiv lærer-elev-relation og for god læseundervisning.

\subsubsection{Lerernes professionalisme}

Lærernes professionalisme bliver her anvendt som en samlet betegnelse for lærernes uddannelse og erfaringsmæssige baggrund. Disse faktorer 
har en afgørende positiv sammenhæng med elevernes læsefærdigheder da det gør læreren i stand til at varetage den enkelte elevs behov (Taube, 1995; Sommer, 1996).

Afsnittet vil se på hvordan uddannelse og erfaring er med til at understøtte lærernes læseundervisning, mens det ikke vil komme nærmere ind på hvordan læreruddannelsen generelt er udformet. Det sker i en særskilt kortlægning af læreruddannelsen i de nordiske lande i Nordisk Ministerråds regi.

Det følgende er baseret på case studier og anden forskningslitteratur om læsning da de internationale læseundersøgelser ikke direkte beskæftiger sig med sammenhængen mellem lærernes uddannelse eller erfaringsgrundlag og elevernes præstationer ${ }^{4}$.

Elevernes første introduktion til læseundervisningen er vigtig for deres fremtidige arbejde med læsning, og derfor er det afgørende at læreren er i stand til at støtte og motivere på en professionel måde. Elevens motivation er afgørende for indlæringen (se kapitel 6). At lære at læse er en stor udfordring for mange elever, og læsning kræver for mange en træning som i omfang overstiger alt hvad man ellers har skullet lære. Elever som får en dårlig start på læseundervisningen, risikerer at havne i en ond cirkel hvor de kører træt i læseundervisningen og forsøger at undgå læsning. Resultatet bliver at eleven ikke får den nødvendige træning (Elbro, 2001; Taube, 2006).

Læseundervisningen bør derfor fra begyndelsen varetages af lærere med de specifikke kvalifikationer inden for fagområdet. Drenge er typisk dårligere disponeret for at modtage undervisning i løbet af de første skoleår end piger, og de vil derfor være mere udsatte for at ende i onde cirkler i forhold til læseundervisning (se kapitel 6).

Drengene læser bedre når de læser om noget de interesserer sig for, og som de kan se en idé i at arbejde videre med. Et studie af 20 svenske lærere viste at lærere der af kolleger blev opfattet som dygtige, og hvis elever klarede sig godt, også var gode til at tage højde for de enkelte elevers behov. Det er især interessant at disse lærere var i stand til at motivere drengene til at læse selvstændigt. Disse timer kaldte en lærer „forskning“, og eleverne kunne her forske i alt hvad de interesserede sig for. På

\footnotetext{
${ }^{4}$ Den eneste som inddrager lærernes uddannelse, er PIRLS, der dog kun ser på sammenhængen mellem elevernes præstationer og uddannelsens længde - og ikke på indholdet i uddannelsen. Undersøgelsen finder ingen signifikant sammenhæng.
} 
den måde fik drengene mulighed for at læse om noget inden for deres interessefelt som de efterfølgende bearbejdede ved at skrive om det de havde læst (Truedson, 1994). Læreren selv forklarede det med at timer med fri læsning ofte vil forbindes med noget feminint, mens det at forske tværtimod forbindes med noget maskulint ${ }^{5}$.

I Danmark blev PISA 2000 gentaget i 2004 blandt alle elever i 9. klasse i København. Et af resultaterne på skoleniveau i PISA-København er at forskellen mellem de fem skoler der giver eleverne de bedste læsefærdigheder og de fem skoler med de dårligste, blandt andet skyldes at lærerne på de bedste skoler modtager meget mere efteruddannelse (Egelund, 2005).

Der er andre eksempler på at uddannelse og erfaring gør læreren bedre i stand til ikke bare at højne det generelle læseniveau i klassen, men også tage sig bedre af elever og grupper med særlige behov. I den sammenhæng vil det være relevant også at benytte sig af forskningen på området. EVA’s evaluering af læsning i den danske folkeskole viser netop at det giver et stort udbytte når viden fra forskningen benyttes i hverdagen. Evalueringen viser også at mange kommuner har gode erfaringer med at have en læsekonsulent. Læsekonsulenten kan bygge bro mellem udviklingen på forskningsområdet og lærernes hverdag ved at holde sig ajour med den nyere forskning og formidle denne gennem kurser for lærerne. Desuden kan læsekonsulenten oprette og koordinere et netværk for skolernes læsevejledere, fx internt i en kommune (EVA, 2005b).

\section{Fokusområde for fremtidige undersøgelser}

Lærere med de rette kvalifikationer er bedre til at undervise i læsning og til at tage højde for drengenes særlige behov som gruppe. Det vil derfor være relevant at se på hvilke kompetencer der kræves i læseundervisningen på forskellige niveauer i grundskolen, og på den baggrund undersøge hvordan man kan sikre at lærerne har de relevante kvalifikationer. Dette kan med fordel ske ved at inddrage forskningen på området.

\footnotetext{
${ }^{5}$ Betegnelsen af timer som „forskning“ har i nogle skolesammenhænge fået et dårligt ry, da det er blevet opfattet som undervisning uden lærerinvolvering og at eleverne kan gøre som de selv vil.
} 


\subsubsection{Lcerernes køn}

Samtlige internationale læseundersøgelser viser at i de deltagende lande er langt de fleste lærere kvinder. Denne tendens gælder også i de nordiske lande hvor kvindelige lærere udgør den største del af det samlede lærerkorps (se fx Elley, 1992 og Lie, 2003). IEA-undersøgelsen viser at der ikke er nogen forskel mellem lærernes køn samlet og kønsforskelle i elevpræstationer (Elley, 1992).

For at se nærmere på hvordan andelen af kvindelige lærere påvirker kønsforskellen i elevernes præstationer, er det nødvendigt at se på andelen af kvindelige modersmålsundervisere. Ser man på modersmålsundervisere, viste IEA-undersøgelsen at der er en sammenhæng mellem andelen af kvindelige lærere og forskellen i drenge og pigers læsefærdigheder i pigernes favør. Blandt elever der modtager læseundervisning af kvinder læser pigerne altså bedre (Mejding, 1994).

En typisk forklaring på at en stor andel af kvindelige lærere vil føre til at pigerne klarer sig bedre, er at de normer og værdier som kommer til at præge arbejdet på skolen, vil være i overensstemmelse med pigernes end drengenes måde at fungere på (Nordal, 1997). Samtidig vil læreren ofte fungere som forbillede for eleverne, og en kvindelig lærer vil derfor appellere mere til pigerne end til drengene. Det vil være mest fremtrædende i de større klasser hvor elevernes identitet som voksen begynder at tage form, og hvor de leder efter rollemodeller.

Sammenhængen mellem andelen af kvindelige lærere og elevernes præstationer er forbundet med problematikken om hvorvidt skolesystemet generelt er indrettet til piger. En norsk analyse af lærernes vurderinger af særlige personlighedstræk som karakteriserer drenge og piger, viser at piger i højere grad tilpasser sig autoriteter end drengene (Nordal, 1997). Analysen viser også at der er en klar sammenhæng mellem autoritetstilpasning og skolefaglige præstationer (Nordal, 1997).

Det generelle billede fra analyser og forskning er at pigerne er tilpasningsdygtige, nøjagtige og samarbejdsvillige, hvorimod drengene er mere uafhængige (Nordal, 1997). Undervisningsformerne i grundskolen er generelt præget af lærerstyring og passiv opgaveløsning som er en form der er mere kompatibel med de tilpasningsdygtige piger end de mere kritiske drenge.

Grundskolen er både præget af mange kvindelige lærere og et undervisningsmiljø som pigerne befinder sig bedre i end drengene. Hvordan de 
to elementer spiller sammen, og hvordan de påvirker kønsforskellen i elevernes præstationer, kan imidlertid belyses nærmere.

Fokusområde for fremtidige undersøgelser

Undervisningsmiljøet og den store andel af kvindelige lærere har en betydning for forskellen i drenges og pigers læsepræstationer. Det vil derfor være relevant at afdække hvordan disse to forhold spiller sammen, hvordan de påvirker eleverne og i hvilket omfang.

\subsubsection{Larersamarbejde}

Når lærerne arbejder sammen om læseundervisningen, kan de dele viden og erfaringer, og det har en positiv indflydelse på læseundervisningen. Faglige miljøer på skolen kan give mulighed for inspiration og sparring omkring tilrettelæggelsen af undervisningen. Det vil medvirke til at højne det faglige niveau blandt lærerne (EVA, 2005b).

Nordlæs-undersøgelsen viser at danske lærere havde mindre samarbejde med andre lærere end lærerne i Sverige og Finland - særligt arbejdede modersmålsundervisere meget mere sammen i Sverige og Finland (Sommer, 1996). En nyere evaluering fra EVA viser at lærerne i Danmark primært arbejder sammen i klasseteam og sekundært i årgangsteam. Lærerne ser egentlig fagudvalget som det mest velegnede forum for deling af viden om læseteorier og materialer, men danskfagudvalget er på de evaluerede skoler enten nedlagt eller stærkt nedprioriteret (EVA 2005b). Dette knytter sig samtidig til spørgsmålet om inddragelse af forskning i læseundervisningen, som blev berørt i afsnit 4.2.1.

I dag er centrale undervisningsplaner omdrejningspunktet for tilrettelæggelsen af læseundervisningen i Norden, mens lokale læseplaner anvendes stadig mindre på grund af centralt fastsatte trinmål. Det lokale arbejde med disse læseplaner er dog stadig nyttigt, og de centrale læseplaner vil kunne bearbejdes i eventuelle faglige miljøer på den enkelte skole således at de centrale udspil kan tilpasses den enkelte skoles betingelser. 
Det vil både være interessant at undersøge omfanget og indholdet af lærersamarbejdet og lærernes erfaringer med lærersamarbejdet, fx gennem case studier.

Fokusområde for fremtidige undersøgelser

Lærernes samarbejde om faglige emner er centralt for kvaliteten af læseundervisningen. Det vil derfor være relevant at se nærmere på hvordan samarbejdet generelt fungerer på skoleniveau. Herunder bør man fokusere på at hvordan samarbejdet kan hjælpe læseundervisningen i en positiv retning gennem bedre læsefaglige miljøer på skolerne.

\subsection{Læsning i skolen}

\subsubsection{Lesematerialet}

De internationale læseundersøgelser ser overordnet ser på tre typer af tekster (se også kapitel 3). De første to er henholdsvis skønlitterære og faglitterære tekster, som i PISA-testmaterialet betegnes sammenhængende tekster, mens den tredje type er såkaldte skematiserede eller ikkesammenhængende tekster - fx grafer og tabeller. Kapitel 3 viste hvilke teksttyper som appellerer mest til henholdsvis drenge og piger, men så ikke på hvordan de forskellige teksttyper blev anvendt i læseundervisningen i de nordiske lande.

PIRLS-undersøgelsen viser netop at der er en positiv sammenhæng mellem anvendelsen af skønlitteratur i undervisningen og elevernes præstationer (Skolverket, 2003b; Mullis 2003a). Den viser samtidig at de tre nordiske lande som deltager i undersøgelsen - Sverige, Norge og Island generelt inddrager mere skønlitteratur i undervisningen end gennemsnittet for alle landene i undersøgelsen (Mullis, 2003a).

IEA-undersøgelsen fra 1994 viser at emnerne i de tekster og opgaver der testes i, også har betydning for hvordan piger og drenge klarer testen. Drengene præsterer dårligst ved tekster om mennesker, dyr (der handler som mennesker) og aktiviteter tilknyttet mennesker. Drengene klarer sig 
lidt bedre, men stadig dårligere end pigerne, ved tekster om neutrale emner (uden mennesker) og naturvidenskabelige emner (Taube, 1997).

Det har også betydning hvilke køn teksterne i læseundersøgelsen handler om, for de 14-årige i IEA. Pigernes overlegenhed i læsefærdighed er større ved tekster hvor hovedpersonen er pige eller kvinde end mand. (Taube, 1997). Undersøgelsen viser også at drenge klarer sig bedre i opgaver med mandlige hovedpersoner. Tendensen er altså at begge køn læser bedst når de kan identificere sig med den eller det de læser om.

Mens samtlige undersøgelser viser at piger klarer sig bedre når de læser skønlitterære tekster, viser PIRLS altså at der er en sammenhæng mellem inddragelsen af skønlitterære tekster og læsefærdigheden. Ud fra et dansk case studie i Esbjerg Kommune ser man det som en mulighed at stimulere drengenes læselyst ved at anskaffe mere litteratur som appellerer mere til drengene (Balslev, 1999).

Fokusområde for fremtidige undersøgelser

De forskellige teksttyper appellerer forskelligt til drenge og piger - fx klarer drenge sig i undersøgelser dårligere med skønlitterære tekster. Derfor bør man undersøge hvilket læsemateriale der stimulerer drengene, og hvordan det kan inddrages i undervisningen.

\subsubsection{Lesetid}

Når man skal lære at læse, er det afgørende at træne meget. Igennem træning opnår eleven en automatisering af læsning hvilket vil sige at eleven kan ser ordene som dele af sætninger og ikke som enkeltstående udfordringer i form af en bogstavkode der skal brydes. Dermed kan tekster begynde at give mening for eleven (Elbro, 2001). Derfor burde der være en sammenhæng mellem jo flere timer eleven bruger på læsning og læseundervisning, jo bedre vil elevens læsefærdigheder blive.

PIRLS-undersøgelsen viser dog at der ikke er en tydelig sammenhæng mellem antal timer brugt på læsning - både som decideret læseundervisning og som en integreret del af andre fag - og læsefærdighed. I analysen er der ikke er forskel på elevernes præstationer i klasser hvor man bruger mange timer (over 6 om ugen) og klasser hvor man bruger få timer (3 
eller mindre om ugen) på at læse (Mullis, 2003a). Ser man på hyppigheden af decideret læseundervisning, ser det heller ikke ud til at have en betydning om lærere bruger tid på dette hver dag eller kun et par gange eller mindre om ugen (Mullis, 2003a). At undersøgelsen viser at der ikke er sammenhænge med elevernes læsefærdigheder, kan skyldes at klasser hvor man bruger meget tid på læseundervisning, kan have et stort antal af elever der har problemer med at læse.

\subsubsection{Arbejdet med lcesning}

Ud over læsetid bør lærer og elever også fokusere på bearbejdningen af det læste som er en vigtig del af læseundervisningen. Det er vigtigt at eleverne får bearbejdet de læste tekster, og på den måde har et sigte med læseprocessen - det er især vigtigt for drengene (Truedson, 1994).

PIRLS-undersøgelsen ser nærmere på forskellige former for hvordan denne bearbejdning kan finde sted, fx om den er skriftlig eller mundtlig, og om den i givet fald foregår som klasseundervisning eller diskussion i grupper (Mullis, 2003a). Ud fra disse brede grupper finder PIRLSundersøgelsen ingen sammenhæng mellem arbejdet med læsning og elevernes præstationer. PIRLS-undersøgelsen ser desuden på hvor ofte lærere inddrager forskellige typer medier som $\mathrm{fx}$ tv og video, hvilket dog heller ikke viser nogen entydig sammenhæng med læsepræstationerne (Mullis, 2003a).

Elbro fremhæver at aktiviteter der hjælper eleven til en bedre forståelse i læsning, karakteriseres ved at eleven omformer teksten fra dens oprindelige ordlyd til en anden - $\mathrm{fx}$ ved at referere indholdet med egne ord eller ved at tegne en tegning eller en graf over teksten (Elbro, 2001).

PIRLS-undersøgelsen opererer med meget brede begreber for arbejdet med læsning og ser alene kvantitativt på sammenhængene med læsefærdigheder. Måske ville det være muligt at give en mere nyttig og vejledende viden til lærerne ved at gennemføre mere kvalitative studier der fokuserer på hvilke øvelser til bearbejdning af det læste der generelt er gode erfaringer med. 
Fokusområde for fremtidige undersøgelser

At bearbejde det læste er afgørende for læseforståelsen. Det kan imidlertid gøres på forskellige måder og med forskellige metoder som dog alle skal være systematiske. Det vil være relevant at undersøge om der er måder at bearbejde en tekst på som er særligt velegnede til drenge. De kan $\mathrm{fx}$ have nemmere ved at bearbejde en tekst ved at tegne den end ved at skrive om den.

\subsubsection{Forholdet mellem lasning og skrivning}

Gennemgangen af PISA 2000 i kapitel 3 viste at drenge klarer sig dårligere i opgaver med åbne svarmuligheder end i opgaver med lukkede svarmulighederne. Drenge er således ikke blot dårligere til at læse end pigerne, de er også dårligere til at skrive. Traditionelt er det at læse inden for sprogforskningen blevet opfattet som en forudsætning for at kunne skrive. Flere forskere er imidlertid blevet stadig mere opmærksomme på samspillet mellem læsning og skrivning - og på at skrivning måske endda kan gå forud for læsning (se fx Liberg, 1993; Elbro, 2001; Trageton 2003). Flere læseforskere er begyndt at påpege ligheden mellem forståelse af talesproget og skriftsproget (Trageton, 2003).

Læsning og skrivning kan ses som led i en læsemetodisk cirkel der forbinder talesproget med skriftsproget - omsætte bogstaver til lyde og igen lyde til bogstaver. Man kan benytte to metoder som indgang til denne cirkel: læsevejen og skrivevejen (Frost, 2000).

Læsevejen begynder ved skriftsproget med at identificere bogstaver, og herefter forbindes bogstaverne med lyde som sættes sammen og danner ord. I denne tilgang fokuserer man meget på arbejdet med bogstaver inden man går videre og til at sætte bogstaverne sammen til ord. Læsevejen er traditionelt blevet anvendt som begyndelse i den læsemetodiske cirkel fordi man har villet bevæge sig fra den mindste enhed til helheden.

Skrivevejen derimod begynder ved at analysere lyde som børnene lærer at omforme til bogstaver. Børn lærer på den måde ved at bevæge sig fra lyd til bogstaver - i modsætning til at begynde med at lære at omsætte bogstaver til lyde. Fordelen ved denne metode er at barnet kan tilegne sig skriftsproget i sit eget tempo - barnet behøver ikke at kunne skrive rigtigt 
for at begynde at lege med skriftsproget. Derfor peger flere forskere på at det er lettere at bevæge sig fra skrivning til læsning end omvendt (Frost, 2000; Elbro, 2001). Der er således sket et skift i opfattelsen af læseindlæringsmetodikkerne blandt en stor gruppe forskere. Disse forskere påpeger dog også vigtigheden i samtidighedsprincippet, dvs. at man ikke kun fokuserer på enten læsning eller skrivning, men at man derimod sørger for at det bliver parallelle processer.

Et problem er ifølge disse forskere at det kan være svært for svage læsere der har lært at læse gennem læsevejen, at bygge bro til skriftsproget. En vigtig pointe i forhold til drenges og pigers læsefærdigheder er derfor at man også bør fokusere på drengenes skriftsprog - både fordi det er en del af læseudviklingen, men også for at sikre at denne del også udvikles hos de læsesvage drenge. En hypotese kunne endda være at drengene ville have nemmere ved at lære at læse på denne måde eftersom de i højere grad kan følge deres eget tempo. I de internationale undersøgelser som PISA vil øget skriftlighed hos drengene uden tvivl gøre at de klarer sig bedre.

It anvendes i undervisningen i stigende grad, og det kan have betydning for den øgede fokus på skrivning i undervisningen, da børn kan begynde at arbejde med skrivning på computeren allerede inden de selv kan skrive bogstaverne (Trageton 2003). Ved at skrive på computere frem for i hånden kan især drengene i højere grad tidligere få lov til selvstændigt at arbejde med skrivningen.

Fokusområde for fremtidige undersøgelser

Det vil være interessant at se nærmere på hvordan de læsemetodikker som går ad skrivevejen, kan anvendes til at møde drengenes særlige behov. Desuden vil det være interessant at se på hvordan brugen af it vil kunne motivere drengene. 


\subsection{Forhold i klassen}

\subsubsection{Klassestørrelse}

Afgørelsen af klassestørrelse har store ressourcemæssige konsekvenser for skolen, og betydningen af klassestørrelse er derfor et vigtigt politisk spørgsmål.

PIRLS-undersøgelsen er baseret på læsetest fra hele klasser. I rapporten gøres der opmærksom på at der statistisk ikke kan påvises en sammenhæng mellem klassestørrelse og læsefærdigheder. Begrundelsen kan blandt andet være at nogle klasser er små fordi eleverne har brug for speciel læsetræning, mens andre klasser kan være små på grund af geografisk placering (Mullis, 2003a).

En analyse af de norske resultater i PIRLS-undersøgelsen viser at klasser med et højt gennemsnitligt læseresultat i Norge har en mindre spredning i læsefærdigheder end klasser med dårlige resultater. Det betyder at klasser med gode læsefærdigheder er mere homogene end klasser med et lavt gennemsnit, og at det høje gennemsnit ikke skyldes at der er nogle få gode læsere i klassen. Den gennemsnitlige klassestørrelse for de tyve bedste norske klasser er lidt større end for de 20 svageste klasser (Solheim, 2003b).

\subsubsection{Intern dynamik i klassen}

Klassens størrelse har en betydning for dynamikken i klassen. Ovenstående norske analyse beskæftiger sig også med hvordan dynamikken i klassen påvirker både de dygtige og de svage elever.

Analysen viser at nogle af de faktorer der adskiller de bedste klasser fra de svageste, kan henføres til miljøet i klassen. Flere elever i de bedste klasser kan lide at gå i skole end elever i de svageste klasser (der er dog også et flertal i de dårligste klasser der kan lide at gå i skole). I den svageste gruppe af elever er der flere elever der oplever at de ikke læser så godt som deres klassekammerater, og flere elever der synes det er vanskeligt at læse højt i klassen. Undersøgelsen viser desuden at de bedste klasser oplever større lærerstabilitet end de svageste (Solheim, 2003b). 


\subsubsection{Arbejdsmiljø i klassen}

I PISA 2000 og 2003 blev eleverne spurgt om miljøet i klassen. Eleverne blev spurgt om der blev hørt efter læreren, om der var brok og uro i klassen, og om eleverne arbejdede godt. I PISA 2003 scorer samtlige nordiske lande under OECD-gennemsnittet på disse parametre, og Norge runder endda feltet af med det dårligste arbejdsmiljø i undersøgelsen (Kjærnsli, 2004).

PISA 2000-resultaterne viser at der er en svag sammenhæng mellem læringsmiljøet og elevernes præstation (Kirsch mfl., 2002). Sammenhængen kan dog skyldes flere forhold, fx at urolige elever er samlet i klasser, eller at de elever der i forvejen læser dårligere, også forstyrrer mere. Det er dog en meget disciplinær form for arbejdsmiljø PISA afdækker, mens en anden undersøgelse måske ville definere et godt arbejdsmiljø på en anden måde og fx afdække om eleverne hjælper hinanden, og om de føler sig trygge ved at udtrykke sig om det læste i klassen.

\section{Fokusområde for fremtidige undersøgelser}

Læringsmiljøet og den interne dynamik i klassen påvirker elevernes præstationer, men det er ikke tydeligt hvordan. Derfor ville det være interessant at se nærmere på hvordan elever påvirker hinandens præstationer, og hvordan man kan fremme de positive påvirkninger.

\subsection{Forhold på skolen}

\subsubsection{Fysiske forhold}

I den norske analyse af klassers læsefærdigheder i forbindelse med PIRLS-undersøgelsen er skolelederen blevet spurgt om 13 eventuelle forhold/mangler der begrænser undervisningen. Forskellen mellem de bedste og svageste klasser er signifikant til fordel for de bedste klasser hvor tendensen er at klasser med et godt læsegennemsnit er på skoler hvor ressourcetilgangen er bedre på de 13 områder. Det gælder specielt $\mathrm{i}$ forhold til skolebygninger og udenomsarealer, udluftningssystemer, belysning og undervisningsfaciliteter (fx klasselokaler) (Solheim, 2003b). 


\subsubsection{Skolens leringsmiljø}

PIRLS-undersøgelsen viser at der er en sammenhæng mellem elevernes læsefærdigheder og om de føler sig trygge på skolen. De elever som ikke følte sig trygge, klarede sig i gennemsnit dårligst. Da eleverne blev spurgt om der inden for den sidste måned var blevet stjålet noget fra dem selv eller fra en anden elev i deres klasse, eller om de havde været udsat for mobning var sammenhængen med læseresultaterne endnu tydeligere. De elever som svarede nej til alle spørgsmålene, klarede sig i gennemsnit bedre end dem som svarede ja (Mullis, 2003a).

Den svenske nationale rapport fremhæver netop at svenske skoleledere og elever i PIRLS-undersøgelsen overordnet mener at det gode skoleklima og en udbredt tryghedsfølelse er en af forklaringerne på Sveriges gode resultater (Skolverket, 2003b).

\subsubsection{Skolebiblioteker}

Skolebiblioteker er en vigtig ressource som har en tydelig sammenhæng med læsefærdighederne (Mejding, 1994). De nordiske lande har generelt gode bibliotekstilbud, og PISA 2000 viser da også en sammenhæng mellem brug af biblioteker (både skole- og folkebiblioteker) og læsefærdigheder. Sammenhængen er mest tydelig i Finland (Lie mfl., 2001; se også kapitel 6) hvor det dog er folkebibliotekerne som gør udslaget. Mens folkebibliotekerne i Finland er meget velforsynede, er skolebibliotekerne langt mindre prioriteret.

Velfungerende skriftsprogsmiljøer, som skolebiblioteker eller andre lokaler eller opsætninger med bøger er en del af en god læseindlæringsproces (Elbro, 2001), og skolebiblioteker kan have en særlig rolle i forhold til at motivere drengene der i udgangspunktet er mindre motiverede for at læse. I den norske afrapportering fra PISA 2000 fremhæver man i forbindelse med en omtale af lukning af biblioteksfilialer at det især kan komme til at gå ud over drengene. I forbindelse med et dansk læseprojekt i Esbjerg Kommune foreslår man at gøre en særlig indsats over for drengene via skolebibliotekerne ved at indrette særskilte drenge- og pigeafdelinger på biblioteket. På den måde kan man indrette skriftsprogsmiljøer som henvender sig til drengene (Balslev mfl., 1999).

Skriftsprogsmiljøer skal imidlertid ikke være afgrænset til biblioteket, men kan samtidig eksistere flere steder på skolen - fx vil det være moti- 
verende at have et spændende udvalg af læsemateriale i selve klasseværelset (Balslev mfl., 1999).

\section{Fokusområde for fremtidige undersøgelser}

Skolebiblioteker og andre skriftsprogsmiljøer kan være en del af en spændende tilgang til læsning for eleverne. Miljøerne kan indrettes så de særligt appellerer til drengene, men det kræver yderligere undersøgelser at klarlægge hvordan man bedst indretter spændende skriftsprogsmiljøer.

\section{Litteratur:}

Balslev mfl. (1999): Når kurven kncekker - et læeseprojekt, Pædagogisk center i Esbjerg, Danmark

Egelund mfl. (2005): PISA-København 2004 - Kompetencer hos elever i 9. klasse i København, Akf Forlaget, Danmark

Elbro, Carsten (2001): Lcesning og lceseundervisning, Gyldendal, Danmark

Elley, W.B. (1994): The IEA Study of Reading Literacy. Achievement and Instruction in Thirty-Two School Systems, Pergamon, England

Elley, W.B. (1992): How in the world do students read?, IEA, Tyskland

Engen mfl. 2005: Leseferdighet i 2. klasse - våren 2005. Delrapport Nasjonalt Senter for leseoplæring og leseforskning, Universitet i Stavanger, Norge

EVA (2003): Skoleudvikling i Chicago, Danmarks Evalueringsinstitut, Danmark

EVA (2005b): Lesning i Folkeskolen, Danmarks Evalueringsinstitut, Danmark

Frost, Jørgen (2000): Bliv venner med skriftsproget!, Dyslexi - aktuellt läsoch skrivsvårigheter nr 1/2000, Norge
Kirsch mfl. (2002): Reading for change, Performance and engagement across countries, Results from PISA 2000, OECD, Frankrig

Kjærnsli mfl. (2004): Rett spor eller ville veier? Universitetsforlaget, Oslo, Norge

Liberg, Caroline (1993): Hur barn lär sig skriva, Studentlitteratur, Lund, Sverige

Lie mfl. (2003): Northern Lights on PISA, University of Oslo, Norge

Mejding, Jan (1994): Den grimme celling og svanerne, DPI, Danmark

Mullis mfl. (2003a): PIRLS 2001 International Report, Boston College, USA

Nordahl, Thomas (1997): Er skolen bedre tilpasset jenter enn gutter?, Bedre Skole 1: 18-25, Norge

Skolverket (2003b): Barns läskompetens - i Sverige och $i$ världen (PIRLS 2001), Skolverket, Sverige

Solheim mfl. (2003b): Hvorfor leser klasser så forskjellig?, Senter for leseforsking, Norge

Sommer mfl. (1996): Nordlas, DPI, Danmark

Taube, Karin (1997): Hur i all världen läser svenska elever?, Skolverket, Sverige 
Taube, Karin (2006): Skillnader mellan pojkars och flickors läsning, artikel Nordisk Ministerråd

Taube, mfl (1995): Svensk läsundervisning i ett internationellt perspektiv, Skolverket, Sverige
Trageton, Arne (2003): Å skrive sig til lesing, Universitetsforlaget, Oslo, Norge

Truedson, Lars (1994): Rum för lärande, Skolverket, Sverige 



\section{Elevniveau}

Den enkelte elevs indstilling til det at læse spiller en afgørende rolle i læseindlæringsprocessen. Dette kapitel fokuserer på faktorer hos den enkelte elev som har betydning for læsefærdigheden. Faktorerne er afhængige af forhold som er beskrevet i de foregående kapitler, fx forældrenes socioøkonomiske baggrund og den undervisning eleverne modtager i skolen.

Først gennemgås elevernes holdning til at læse, derefter ses på deres læsevaner. Dernæst undersøges hvordan eleverne bliver påvirket af deres medieforbrug, og til sidst hvordan biologiske forhold har indflydelse på læsefærdighederne.

\subsection{Elevernes holdning til at læse}

PISA 2000, 2003 og PIRLS 2001 viser alle at der en tydelig sammenhæng mellem elevernes holdning til at læse og deres læseresultater. En positiv holdning betyder bedre læsefærdigheder. I PIRLS 2001 er der udregnet et samlet indeks for elevernes holdning til læsning på baggrund af fem udsagn (såsom „Jeg kan lide at tale om bøger“ eller „Jeg læser kun, hvis jeg skal.“). I de nordiske lande er der ikke store forskelle i elevernes holdning til at læse, dog ligger de svenske elevers holdning lige over det internationale gennemsnit, mens de islandske og norske elever ligger under (Mullis, 2003a).

I PISA 2000 er der beregnet et tilsvarende holdnings-indeks på baggrund af ni udsagn. Her overgås Finland kun af to lande (Portugal og Mexico) når elevernes gennemsnitsværdier for læseinteresse beregnes. De danske og islandske elevers interesse for at læse ligger omkring gennemsnittet, mens de svenske elever er mindre interesserede (Lie, 2001). 
PISA 2000 viser at læseengagementet er højest blandt pigerne, og i de nordiske lande er engagementet blandt pigerne højere end i de fleste af de øvrige lande i undersøgelsen. Finland ligger igen i toppen (Kirsch, 2002). PIRLS 2001 viser det samme mønster, nemlig at pigernes holdning til at læse er mere positiv end drengenes, og at kønsforskellen i de nordiske lande er relativt højt i forhold til de øvrige deltagende lande. (Mullis, 2003a).

Analysen af PISA 2000 viser desuden at elevernes læseengagement kan opveje den socioøkonomiske baggrund. De elever der har forældre med en lav socioøkonomisk status (erhvervsmæssigt), men som samtidig er meget engagerede læsere, har bedre læsefærdigheder end elever med lav læseengagement, men med forældre der har en middel eller høj socioøkonomisk status (Kirsch mfl., 2002).

Fokusområde for fremtidige undersøgelser

En af forudsætningerne for at opnå gode læsefærdigheder er at eleven har en positiv holdningen over for det at læse - hvilket især drengene mangler. Derfor bør en målrettet indsats for mere læsning og større læseengagement rettes til drengene. Desuden vil udbredelse af større læseengagement til alle elever bidrage til at bryde den sociale arv. Det er derfor oplagt at undersøge specielt drenges motivation for at læse og hvilke kampagner der kan fremme læselysten.

\subsubsection{Elevernes selvvurdering}

I IEA- og PIRLS-undersøgelserne er de henholdsvis 9- og 10-årige elever blevet spurgt om hvor gode de selv vurderer at de er til at læse. I IEAundersøgelsen er svaret på spørgsmålet den faktor der har størst statistisk sammenhæng med læsepræstationen, det vil sige at elever der vurderer sig selv som gode, sandsynligvis også klarer testen godt. Blandt de nordiske lande vurderer de svenske elever sig selv bedst, derefter kommer i rækkefølge Island, Danmark, Norge og Finland. De finske elever har altså en ydmyg selvvurdering selv om de præsterer nogle meget gode læseresultater (Taube, 1997).

Selvvurderingerne forklarer måske ikke hvorfor nogle elever er gode til at læse og andre mindre gode, men at eleverne har en meget god for- 
nemmelse af hvor gode de selv er til at læse. Grunden til de finske elevers mindre positive selvvurdering kan være at kravene til eleverne er meget høje, og PISA 2000 viser også at finske elever reagere negativt på pres fra lærerne (Kirsch, 2002).

I Norge og Sverige viser PIRLS-undersøgelsen at der er signifikant forskel på pigers og drenges selvopfattelse fordi flere piger vurderer at deres læsefærdigheder er gode. I Island er der ingen forskel på pigers og drenges selvopfattelse (Mullis, 2003a).

I både IEA- og PISA-undersøgelserne har eleverne svaret på spørgsmål om egenskaber der betyder at de bliver gode læsere. I IEAundersøgelsen mener de svenske elever at det er vigtigt at man kan lide at læse, at man har tid til at læse, og at man kan koncentrere sig. Sidstnævnte er der også spurgt ind til i PISA. Det gælder for begge undersøgelser at der ikke er forskelle på hvordan piger og drenge svarer (Taube, 1997; Lie, 2003). Med andre ord er det ikke drengenes opfattelse at deres mindre gode læsefærdigheder skyldes manglende koncentration.

\subsection{Elevernes læsevaner}

Forskellen i elevernes holdning og interesse for at læse afspejler sig også i deres faktiske læsevaner. IEA-undersøgelsen og PIRLS viser at der er en sammenhæng mellem hvad eleverne læser i fritiden og hvor ofte og deres læsefærdigheder.

\section{Lesestof}

IEA-undersøgelsen viser at finske, svenske og norske 9-årige topper listen med hensyn til frivillig læsning generelt. Der er forskel på hvad det er drenge og piger læser. I alle lande læser pigerne bøger oftere end drengene, mens drengene oftere end pigerne læser tegneserier og instruktioner. Det er desuden en tendens at 9-årige der læser bøger og tegneserier i fritiden, er bedre læsere end dem der næsten aldrig læser. At tegneserier har en positiv effekt, har overrasket, men Elley fremfører at fordelen ved at læse tegneserier kan være at barnet kobler tekst og billeder under motiverende forhold og løbende sammenfatter det til handlingen i historien (Taube, 1997; Elley, 1994). 
Det er et særligt kendetegn ved de nordiske lande at avislæsning er relativt mere udbredt end læsning i magasiner og bøger (Elley, 1992).

\section{Omfanget af lcesning i fritiden}

PIRLS viser at de elever der læser mest i fritiden, klarer læsetesten bedst, og det er pigerne der læser mest. Når der kigges nærmere på de nordiske lande Island, Norge og Sverige, er der imidlertid også en væsentlig forskel. Andelen af piger i Sverige og Island der læser historier og romaner mindst en gang i ugen, er 75-77\%, mens det kun gælder for $56 \%$ af de norske piger. Forskellen mellem landene gør sig også gældende ved drengene (Norge $32 \%$, Island $62 \%$ og Sverige 58 \%) (Mullis, 2003a). Resultaterne fra PISA 2000 viser også at specielt de norske drenge ikke læser i fritiden. Det skal dog tilføjes at forskellen mellem drenge og pigers læsning i fritiden er størst i Finland og Danmark (Lie, 2003).

Trendstudiet der gør det muligt at sammenligne de svenske og islandske resultater fra IEA i 1991 med resultater fra 2001, viser at flere islandske elever i 2001 læser dagligt (51 \%), men andelen af svenske elever der læser dagligt, er faldet. En tendens der også ses blandt de øvrige lande i trendstudiet (Mullis, 2003a).

De svenske elever har de bedste læsefærdigheder i PIRLS-undersøgelsen, og de islandske elever klarer sig bedre end de norske elever. En af forklaringerne kan være at de svenske og islandske elever i højere grad interessere sig for at læse og faktisk gør det. Her skal det fremhæves at forklaringen kan gå begge veje: Gode læsevaner kan betyde gode læsefærdigheder, men omvendt kan gode læsefærdigheder også afspejle at eleverne har mere lyst til at læse - læsevaner i fritiden og læsefærdigheder forstærker hinanden.

\section{Leseprofiler}

I forbindelse med PISA 2000 er der statistisk konstrueret fire læseprofiler i forhold til hvor ofte og hvor varieret eleverne læser henholdsvis magasiner, aviser, tegneserier, skønlitteratur og faglitteratur.

- $\quad$ Profil 1 består af den gruppe elever der læser mindst og mindst varieret. 
- $\quad$ Profil 2 er de elever der ofte læser magasiner og aviser, og hvor der er en moderat variation i det de læser.

- I profil 3 er læsningen mere varieret, og eleverne læser oftere. I profil 3 læser eleverne magasiner, aviser og tegneserier og i moderat omfang skøn- og faglitteratur (Kirsch, 2002).

- I I profil 4 læser eleverne varieret og ofte, men med fokus på længere tekster som skøn- og faglitterære tekster og i meget mindre grad tegneserier.

Analysen af læseprofilerne og læsefærdigheder viser at der er en tydelig sammenhæng mellem elevernes læseprofiler og deres læsefærdigheder. Eleverne med læseprofil 4 læser bedre end eleverne med profil 1 (Kirsch, 2002).

I de nordiske lande fordeler eleverne sig forskelligt i forhold til profilerne. I Island, Finland, Norge og Sverige har fra 6 til $11 \%$ af eleverne profil 1, mens det gælder for $18 \%$ af de danske elever. Halvdelen eller flere af de nordiske elever har læseprofil 3, undtagen Sverige hvor lidt mere end en tredjedel har denne profil. Dette skyldes i høj grad at flere af de svenske elever end de øvrige nordiske elever har læseprofil 4 (Kirsch, 2002).

Fordelt på køn viser PISA 2000 at drengene i højere grad end pigerne hovedsageligt læser aviser, magasiner og tegneserier i stedet for bøger. Det betyder at en tredjedel af drengene har læseprofil 3, mens en fjerdedel af pigerne har denne profil. Det modsatte gør sig gældende for profil 4, hvor en større andel af pigerne matcher profilen end blandt drengene. I profil 1 og 2 er forskellen mellem kønnene mindre og mere varieret blandt de nordiske lande (Kirsch, 2002).

Analysen af PISA-resultaterne viser også en stærk sammenhæng mellem læseprofilerne og adgangen til bøger i hjemmet (beskrevet i afsnit 4.1.3). Elever med læseprofil 4 som læser varieret materiale inklusive bøger, har adgang til mere læsemateriale hjemme end eleverne med profil $1-3$. Det er tydeligt at elever med adgang til mange bøger hjemme har en mere varieret læseprofil (Kirsch, 2002).

En statistisk analyse af PISA 2000-resultaterne viser at den faktor der har størst betydning for forskellen mellem kønnene, er elevernes holdning til og engagement i at læse, og dernæst har det at læse i fritiden betyd- 
ning. (Lie, 2003). Drengenes mindre positive holdning til at læse kan altså have meget stor betydning for kønsforskellen i læsefærdigheder.

\section{Fokusområde for fremtidige undersøgelser}

At træne læsning er afgørende for udviklingen af gode læsefærdigheder. Det vil derfor være relevant at se nærmere på elevernes læsevaner og læseprofiler, specielt drengenes. Desuden vil det være interessant at belyse i hvilken grad de nordiske skoler udvælger læsestof der tager særlige hensyn til kønnene. Det kan derfor undersøges om læsning af kortere og mere overkommelige tekster, fx faglitteratur og tegneserier, kan give eleverne og specielt drengene større lyst til at læse og dermed efterhånden lyst til også at læse længere tekster og bøger. Dermed kan man også afdække om man skal gøre mere for at motivere drengenes lyst til at læse.

\subsubsection{Forceldrenes engagement i børnenes lcesning}

I PIRLS 2001 har forældre til elever i testen besvaret spørgsmål om forhold før skolestart der kan have betydning for læsefærdighederne. Spørgsmålene om førskoleaktiviteter er samlet $\mathrm{i}$ et indeks der angiver læseaktiviteter i hjemmet før skolestart, fx om forældrene har læst bøger med børnene, sunget sange, leget ordlege osv. (Solheim, 2003a og 2003c).

Der er en statistisk positiv sammenhæng mellem forældrenes læseaktiviteter med børnene før skolestart og elevernes læsefærdigheder i testen. Det samlede internationale gennemsnit viser at halvdelen af eleverne (52 \%) har forældre der i høj grad har foretaget læseaktiviteter med børnene inden skolestart. Blandt de nordiske lande er det kun Island der ligger over gennemsnittet for andelen af forældre med høj læseaktivitet. Sverige og Norge ligger noget under gennemsnittet (Island $53 \%$, Sverige $41 \%$ og Norge $47 \%$ ).

At læse bøger højt for børnene inden skolestart er den faktor i „førskole“-indekset der har størst betydning for elevernes læsefærdigheder (Mullis, 2003a), og det er forældre i Island, Norge og Sverige gode til. De tre lande ligger langt over gennemsnittet for forældre der læser ofte.

I PIRLS-undersøgelsen har forældrene også svaret på hvor ofte de på tidspunktet for læsetesten læser for deres børn og taler med børnene om 
det de læser. Der er en positiv sammenhæng for de islandske, norske og svenske elever mellem børnenes læsepræstation og hvor ofte forældrene taler med dem om hvad de læser (Mullis, 2003a).

\subsubsection{Elevernes anvendelse af biblioteker}

At have adgang til og anvende biblioteker påvirker også elevernes læsefærdigheder positivt. I Sverige viser IEA-undersøgelsen blandt 14-årige elever at flittige brugere af biblioteket læser bedre end mindre flittige brugere. Undersøgelsen viser også at de svenske piger går mere på biblioteket end drengene (Taube, 1997)

En af forklaringerne på de finske elever klarede sig så godt i PISAundersøgelserne, kan være at de hyppigt bruger biblioteket. Finske elever topper listen over elever der går på biblioteket. Hele $44 \%$ af de finske elever har i PISA 2000 svaret at de låner bøger mindst en gang om måneden, mens OECD-gennemsnittet er $26 \%$. Sverige, Norge og Island ligger under OECD-gennemsnittet (24-20 \%) (Välijärvi, 2002b).

Andelen af danske elever der låner bøger på biblioteket mindst en gang om måneden, er næsten lige så høj som den finske, nemlig 42 \%. I Danmark er den statistiske sammenhæng mellem biblioteksbesøg og læsefærdigheder svagere end i Finland (Välijärvi, 2002b; Lie, 2001). Det betyder at selv om de danske elever låner bøger lige så ofte som de finske, så har det ikke den samme betydning for deres læsefærdigheder.

Trendstudiet hvor Island og Sverige deltog, viser at der er en tendens til at de islandske og især de svenske børn bruger biblioteket mindre. I 1991 svarede over halvdelen (58 \%) af de svenske elever at de lånte bøger på biblioteket mindst en gang om ugen, mens det kun gjaldt for en tredjedel af eleverne i 2001. Analyse viser dog også at reduktionen af biblioteksbesøg ikke er sket i så høj grad blandt børn med andet sprog og færre bøger hjemme (Skolverket, 2003b).

I PIRLS har de norske elever svaret på hvor ofte de låner bøger på skolen eller biblioteket. Eleverne fordeler sig i næsten tre lige store grupper: 31 \% låner bøger mindst en gang om ugen, 39 \% låner bøger en til to gange om måneden, mens resten gør det sjældent eller aldrig. I Norge er der forskel på drenges og pigers biblioteksvaner. Pigerne låner oftere bøger, mens drengene i højere grad har svaret at de sjældent eller aldrig låner bøger (Solheim, 2003a; 2003c). 
Fokusområde for fremtidige undersøgelser

Brugen af folkebiblioteker kan være et vigtigt element i at få børn til at læse i fritiden. Det er dog interessant at undersøge forskellen i biblioteksvaner i de nordiske lande da de danske elevers lån af bøger ikke giver de samme læseresultater. Det bør også undersøges hvordan folkebibliotekerne kan inddrages i fx læsekampagner og mere vedvarende initiativer til at forbedre læsning også for voksne da deres læsevaner påvirker børnenes.

\subsection{Medier - tv og computere}

Flere læseundersøgelser viser at der en sammenhæng mellem børnenes tv-forbrug og it-anvendelse og deres læsefærdigheder. Blandt andet viser det sig at moderat brug af tv og computere giver gode læsefærdigheder, mens de elever der ikke bruger computere, opnår dårlige læsefærdigheder.

Dette afsnit beskriver sammenhængen mellem elevernes mediebrug derhjemme og deres læsefærdigheder.

\section{Tv-forbrug}

Børns tv-forbrug har ikke nødvendigvis en skadelig effekt på deres læsefærdigheder. IEA-undersøgelsen fra 1991 viser at i Finland, Norge og Sverige er gruppen af børn som i gennemsnit ser 3,5 times fjernsyn om dagen, de bedste læsere i 3. klasse. Ser børnene mere end 3,5 timer om dagen, falder læsefærdighederne imidlertid drastisk (Elley, 1992).

I PIRLS 2001 har eleverne svaret på hvor mange timer de ser tv og video på en hverdagsaften. Samlet internationalt ser $43 \%$ af eleverne tv mindre end 1 time om dagen, mens $45 \%$ ser tv i 1-5 timer hver dag. Der er ingen entydig sammenhæng mellem tv-forbruget og læsefærdighed. I Norge er det de elever der ser tv i 3-5 timer om dagen, der klarer læsetesten bedst, mens det er eleverne der ser tv i 1-2 timer om dagen i Sverige og Island der klarer sig bedst. I Norge og Island ser mere end halvdelen af eleverne tv mindre end 1 time om dagen. (Mullis, 2003a). 
I Finland lyder forklaringen på sammenhængen mellem at se forholdsvis meget tv og gode læsefærdigheder blandt andet at børn ofte ser programmer på et fremmed sprog, og at børnene derfor øver deres læsning ved at læse undertekster (Halinen mfl., 2005).

\section{Computere}

I PISA 2000 har eleverne i 22 lande, herunder Danmark, Finland, Norge og Sverige, svaret på hvor ofte de anvender computere, og hvad de bruger den til. Resultaterne viser at der er en positiv sammenhæng mellem moderat anvendelse af computere og læsefærdigheder.

De svenske og norske unge er de mest flittige brugere af computere derhjemme. De danske elever bruger computeren mest i skolen som del af undervisningen til fx stavning og oplæg (overheads). I de nordiske lande bruger $65-77 \%$ af eleverne internettet mindst et par gange i løbet af ugen - mere end en tredjedel af eleverne i Sverige, Norge og Danmark bruger internettet næsten hver dag. I Sverige, Finland og Danmark er drengene mest interesseret i computere, og kønsforskellen er størst i Danmark (Lie mfl., 2003).

Undersøgelser af finske unges anvendelse af computere viser at selv om drenge bruger mere tid på computere end piger, så bruger pigerne mere tid end drengene på at skrive e-mail og lige så meget tid som drengene på at chatte. Drengene bruger mere tid end pigerne på teknik og spil (Lie mfl., 2003).

I forbindelse med PISA 2000 er der udarbejdet et indeks over hvad eleverne anvender computere til og hvor ofte. I indekset opdeles eleverne i fem grupper gradueret efter hvor ofte eleverne anvender computere. De elever der anvender computeren næstmindst eller næstmest, har de bedste læsefærdigheder. Moderat brug af computer giver tilsyneladende bedre læsefærdigheder, mens analysen også viser at elever der ikke anvender computere, klarer sig dårligst i læsetesten (Lie mfl., 2003).

Pigerne har i alle grupper bedre læsefærdigheder end drengene, men det er interessant at kønsforskellen er mindst i gruppen af elever der bruger computer mest. I Danmark er forskellen næsten udlignet. Forskellen er til gengæld størst blandt de elever der ikke anvender computeren (Lie mfl., 2003). 


\section{Fokusområde for fremtidige undersøgelser}

Det vil være relevant at undersøge hvordan brug af computere påvirker elevernes læsefærdigheder og om der er forskel på drenges og pigers anvendelse af computeren. I forhold til drengene vil det være interessant at se på brugen af it, idet mange drenge læser i forbindelse med computerspil, og drenges læsning i fritiden kunne muligvis øges herigennem og dermed træne læsefærdighederne.

\subsection{Biologiske forklaringer}

Forskning tyder på at hormoner og hjernens organisation og funktion har betydning for forskellen på drenges og pigers læsefærdigheder.

\section{Hormonelle forhold}

De hormonelle forhold bestemmer hvordan drenge og piger udvikler sig fra barn til voksen.

Drengene udvikler sig generelt langsommere end pigerne og kommer senere i puberteten. Drengene er mere skrøbelige hvilket $\mathrm{fx}$ viser sig ved at de er mere syge end pigerne. Denne skrøbelighed gør drengene mere usikre og utrygge i deres opvækst hvilket i skolen kan vise sig ved at de kommer til at virke urolige og forstyrrende (Sataøen, 2004; Nordal, 1997).

Pigernes biologiske forudsætninger er langt bedre end drengenes. De er ikke nær så syge som drengene - der er blandt andet en mindre børnedødelighed. Pigerne vil derfor generelt opleve en mere tryg udvikling, og deres adfærd i skolen vil dermed også være mere tilpasset (Sataøen, 2004; Nordal, 1997).

\section{Hjernens udvikling}

Hjerneforsker Ann-Elisabeth Knudsen har sammenskrevet og analyseret meget af den nyere hjerneforskning, og ifølge hende udvikles drenges og pigers hjerner forskelligt. Forskellene kan deles ind i tre områder: hjerne- 
bjælkens størrelse, hjernemodning og kønshormonernes indflydelse på læringspotentialet (EVA, 2005; Knudsen, 2002).

Når børnene starter i skolen ved seksårsalderen, er pigernes hjernebjælke ca. dobbelt så tyk som drengenes. Hjernebjælken er forbindelsen mellem de to hjernehalvdele, og den sikrer at de to hjernehalvdele kan kobles til hinanden. De to hjernehalvdele fungerer forskelligt. Den venstre hjernehalvdel fungerer digitalt, dvs. at den opdeler oplevelser og situationer i enkeltdele, mens den højre halvdel af hjernen tænker analogt, dvs. i helheder, hele meninger og mønstre (EVA, 2005; Sataøen, 2004; Knudsen, 2002).

På grund af deres mere udviklede hjernebjælke vil pigerne have en neurologisk fordel. Forskellen i tykkelsen af hjernebjælken betyder ikke at der er forskel på drenges og pigers intelligens, men at de har forskellige indlæringspotentialer. Pigerne har bedre mulighed for at koble de to hjernehalvdele, og derfor er de bedre til at gå fra enkeltdele (det digitale) til helheder (det analoge). Det betyder i forbindelse med læselæring at piger lettere kan sammensætte de enkelte bogstaver og ord til selve historien som helhed og omvendt gå fra en historie som helhed til enkelte ord og bogstaver (EVA, 2005; Sataøen, 2004; Knudsen, 2002).

Hjernemodningen hos piger og drenge sker ligeledes i forskellige tempi hvilket har betydning for blandt andet koncentrationsevnen og empati. Der kan være halvandet til to års forskel i pigers og drenges hjernemodning når de starter i skolen ved seksårsalderen. Det betyder ifølge Ann-Elisabeth Knudsen at seksårige piger i skolen kan koncentrere sig om opgaver i dobbelt så lang tid som jævnaldrende drenge (EVA, 2005; Sataøen, 2004; Knudsen, 2002).

Det tredje område er kønshormonets indflydelse på hjernens udvikling som struktur. Forskning har hidtil vist at drenge under indflydelse af testosteron udvikler et specialiseret neuralt netværk hvor de primært bruger højre hjernehalvdel.

Til gengæld har forskningen endnu ikke påvist at østrogen har indflydelse på hjernens udvikling som struktur, og pigerne har lige adgang til begge hjernehalvdele. Piger udvikler derfor et bredt neuralt netværk (EVA, 2005; Knudsen, 2002). Det betyder i sammenhæng med konklusionerne ovenfor at drengene potentielt tænker mere i helheder og kan have sværere ved at koncentrere sig i indskolingen hvor der er fokus på at lære bogstaver og ord. 


\section{Biologiske forklaringer i læeseundersøgelserne}

Den sproglige udvikling er ikke mindst relevant i spørgsmålet om tidspunktet for hvornår børn bør begynde i skolen. Elley (1992) konkluderer på baggrund af IEA-undersøgelsen at blandt de børn der har modtaget formel læseundervisning allerede fra femårsalderen, klarer drengene sig dårligere end pigerne (W. B. Elley, 1992). I PIRLS-undersøgelsen viser analysen af elevernes læsefærdigheder og alderen for skolestart dog ingen klar sammenhæng. Blandt landene med høje læseresultater er eleverne i fx Holland startet i skole når de er seks år, mens eleverne i England starter når de er fem år. Tilsvarende starter eleverne i de lande der klarer sig dårligt i testen, også som både fem-, seks- og syvårige i henholdsvis Belize, Argentina og Iran (Mullis mfl., 2003).

\section{Fokusområde for fremtidige undersøgelser}

Biologiske faktorer har betydning for drenges og pigers modtagelighed over for læseundervisning. Det vil derfor være relevant at få klarlagt hvordan de biologiske forskelle indvirker på læsefærdighederne, og hvordan man kan tage højde for forskellene i selve læseundervisningen.

\section{Litteratur:}

Elley, W. B. (1994): The IEA Study of Reading Literacy. Achievement and Instruction in Thirty-Two School Systems, Pergamon, England

Elley, W.B. (1992): How in the world do students read?, IEA, Tyskland

EVA (2005a): Køn, karakterer og karriere, Danmarks Evalueringsinstitut, Danmark

Halinen et al.(2005): A Land of Readers, Educational Leadership Vol. 63, 2

Kirsch mfl. (2002): Reading for change, Performance and engagement across countries, Results from PISA 2000, OECD, Frankrig
Knudsen, Ann-Elisabeth (2002): Pæne piger og dumme drenge, Schønberg, Danmark

Lie mfl. (2003): Northern Lights on PISA, University of Oslo, Norge Mullis mfl. (2003a): PIRLS 2001 International Report, Boston College, USA

Nordahl, Bertill (1997): Pigerne og drengene, Forlaget Nielsens, Danmark

Sataøen, Svein Ole (2004): Drengeliv - i familie, børnehave, skole og blandt venner, Akademisk forlag, Norge.

Skolverket (2003b): Barns läskompetens i Sverige och världen, PIRLS 2001, Skolverket, Sverige 
Solheim mfl. (2003a): En norsk kortversjon av den internasjonale rapporten om 10-åringers lesekunnskaper, Senter for leseforsking, Norge Solheim mfl.(2003c): Slik leser 10åringer i Norge, Senter for leseforsking, Norge

\section{Litteraturoversigt}

Allerup mfl. (2001): Færdigheder i læsning og matematik, Folkeskolen år 2000, Danmark

Andersen mfl. (2001): Forventninger og færdigheder - danske unge i en international sammenligning, AKF, DPU og SFI, Danmark

Balslev mfl. (1999): Når kurven knækker - et læseprojekt, Pædagogisk center i Esbjerg, Danmark

Danmarks Teknologisk Institut (2005): Explaining Student Performance, DTI, Danmark

Egelund, mfl. (2005): PISA-København 2004 - Kompetencer hos elever i 9. klasse i København, Akf Forlaget, Danmark

Elbro, Carsten (2001): Læsning og læseundervisning, Gyldendal, Danmark

Elley, W. B. (1994): The IEA Study of Reading Literacy. Achievement and Instruction in Thirty-Two School Systems, Pergamon, England

Elley, W.B. (1992): How in the world do students read?, IEA, Tyskland

Engen mfl. 2005: Leseferdighet i 2. klasse - våren 2005. Delrapport Nasjonalt Senter for leseoplæring og leseforskning, Universitet i Stavanger, Norge

EVA (2003): Skoleudvikling i Chicago, Danmarks Evalueringsinstitut, Danmark
Taube, Karin (1997): Hur i all världen läser svenska elever?, Skolverket, Sverige

Välijärvi mfl. (2002b). The Finnish success in PISA - and some reasons behind it, PISA 2000, Institute for Educational Research, University of Jyväskylä, Finland

EVA (2005a): Fokus på læring, Danmarks Evalueringsinstitut, Danmark EVA (2005b): Køn, karakterer og karriere, Danmarks Evalueringsinstitut, Danmark

EVA (2005c): Læsning i Folkeskolen, Danmarks Evalueringsinstitut, Danmark

Frost, Jørgen (2000): Bliv venner med skriftsproget!, Dyslexi - aktuellt läsoch skrivsvårigheter nr 1/2000; Norge

Halinen et al.(2005): A Land of Readers, Educational Leadership Vol. 63, 2

Kirsch mfl. (2002): Reading for change, Performance and engagement across countries, Results from PISA 2000, OECD, Frankrig

Kjærnsli mfl. (2004): Rett spor eller ville veier? Universitetsforlaget, Oslo, Norge

Knudsen, Ann-Elisabeth (2002): Pæne piger og dumme drenge, Schønberg, Danmark

Liberg, Caroline (1993): Hur barn lär sig skriva, Studentlitteratur, Lund, Sverige

Lie mfl. (2003): Northern Lights on PISA, University of Oslo, Norge

Mandag Morgen (2004): Læseforskning ignoreres i danske skoler, Mandag Morgen nr. 10, 8.3.2004, s. 5-9, Danmark

Mejding, Jan (1994): Den grimme ælling og svanerne, DPI, Danmark 
Mejding, Jan (2004): PISA 2003 - danske unge i en international sammenligning, DPU, Danmark

Mullis mfl. (2003a): PIRLS 2001 International Report, Boston College, USA Mullis mfl. (2003b): PIRLS trends in Childrens Reading Literacy Achievement 1991-2001, Boston College, USA

Nordahl, Bertill (1997): Pigerne og drengene. Forlaget Nielsens, Danmark

Nordahl, Thomas (1997): Er skolen bedre tilpasset jenter enn gutter?, Bedre Skole 1: 18-25, Norge

Sataøen, Svein Ole (2004): Drengeliv - i familie, børnehave, skole og blandt venner. Akademisk forlag, Norge

Skolverket (2003a): Läsförståelse hos elever med utländsk bakgrund, Skolverket Rapport 227, Sverige

Skolverket (2003b): Barns läskompetens - i Sverige och i världen (PIRLS 2001), Skolverket, Sverige

Skolverket (2005): Beskrivande data 2005, Skolverket, Sverige

Solheim mfl. (2003a): En norsk kortversjon av den internasjonale rapporten om 10-åringers lesekunnskaper, Senter for leseforsking, Norge

Solheim mfl. (2003b): Hvorfor leser klasser så forskjellig?, Senter for leseforsking, Norge

Solheim mfl.(2003c): Slik leser 10åringer i Norge, Senter for leseforsking, Norge
Sommer mfl. (1996): Nordlæs, DPI, Danmark

Sommer mfl. (1997): Læsning - Hvad kan vi? Hvad vil vi?, Undervisningsministeriet, Danmark

Taube mfl. (1995): Svensk läsundervisning i ett internationellt perspektiv, Skolverket, Sverige

Taube, Karin (1997): Hur i all världen läser svenska elever?, Skolverket, Sverige

Taube, Karin (2006): Skillnader mellan pojkars och flickors läsning, artikel Nordisk Ministerråd

Trageton, Arne (2003): Å skrive sig til lesing, Universitetsforlaget, Oslo, Norge

Truedson, Lars (1994): Rum för lärande, Skolverket, Sverige

Undervisningsministeriet (2005): Rapport fra Udvalget til forberedelse af en national handlingsplan for læsning, Undervisningsministeriet, Danmark

Välijärvi mfl. (2002): Suomen Tulevaisuuden osaajat, University of Jyväskylä, Finland

Välijärvi mfl. (2002). The Finnish success in PISA - and some reasons behind it, PISA 2000, Institute for Educational Research, University of Jyväskylä, Finland

Wagner, Åse K. H. (2004): Hvordan leser minoritetspråklige elever I Norge?, Nasjonalt senter for leseopplæring og leseforsking, Norge 


\section{Executive Summary}

This report analyses the reading skills of pupils in primary and lower secondary school in the Nordic countries and the reasons why the reading skills differ between the countries and between boys and girls.

The Nordic Council of Ministers has ordered the analysis from the Danish Evaluation Institute. The background to the analysis is the performance of Nordic pupils in the PISA surveys. The reading skills of pupils have been illustrated by means of the international reading surveys from IEA and PISA since 1991. The explanation factors underlying the results of the reading surveys have subsequently been analysed on the basis of other Nordic surveys and relevant research.

This summary briefly explains the results of the international surveys and presents a proposal for areas to be examined in future and where additional efforts can be made to enhance pupils' reading skills and reduce the differences between the skills of boys and girls.

\section{Reading skills of Nordic pupils}

The international reading surveys show that Nordic pupils are not all equally good at reading. In Norway and Denmark, pupils' reading skills are average in an international context, whereas Swedish and Icelandic pupils do nicely and are found in the best half, the Swedish pupils performing best. Finally, the surveys show that Finnish pupils are doing better on an international scale than pupils from all other countries in the reading surveys.

The surveys also reveal that girls read better than boys and that there are high differences between the reading skills of boys and girls in the Nordic countries, not least in comparison with other European and over- 
seas countries. However, the difference between boys and girls is virtually the same in all the Nordic countries.

The significance of the socio-economic background to reading skills

The international surveys show that the barriers of social inheritance are far from being dismantled in the Nordic school systems - the educational level of parents is particularly significant to the performance of pupils in the reading tests. However, the levels of pupils' reading skills differ greatly in the Nordic countries. This report and other former surveys conclude that one of the reasons behind the Finnish reading success is that the Finnish schools are able to lessen the influence of social inheritance. The analysis of the PISA results 2003 in Norway shows that the effect of the socio-economic background is most evident among girls.

Focus areas of future surveys

It will be relevant to examine why Finland, for instance, is better than the other Nordic countries at dismantling socio-economic barriers. It will also be relevant to examine the significance of the socio-economic status in the Nordic countries, how schools take pupils' backgrounds into consideration and why the socio-economic background is of greater significance to girls.

\section{Pupils' attitudes to reading}

It is very important that pupils are committed and motivated in the process where they learn to read and when they are to continue the work on reading. Their attitudes to reading in their spare time obviously reflect the parents' attitudes to reading to some extent, which are often based on their socio-economic backgrounds. Even though the two are often related, the pupils' attitudes to reading play a bigger role than the socio-economic background - the barriers of social inheritance can thus be dismantled by making the pupils more positive to reading.

The difference between boys and girls is also clear when it comes to the attitude to reading. Girls are more positive about reading in their spare time than boys, and this is an important reason for the big differences in reading performance. 
Focus areas of future surveys

It will be relevant to examine and analyse how boys can be motivated to read and what targeted efforts can be made to further their interest in reading. The campaigns can contribute to boosting the interest in reading and thus the reading skills and should mainly target boys. Moreover, greater reading commitment among all pupils will contribute to dismantling the barriers of social inheritance.

The importance of libraries to reading

Libraries play a key role in pupils' access to books. The public library is very well established and available in Finland and Denmark, and the pupils in both countries go to the library frequently. The very different reading results of pupils in the two countries demonstrate, however, that there is no connection between pupils' use of libraries and their reading skills.

Focus areas of future surveys

It will be relevant to examine the difference in library habits in the Nordic countries and find out why Danish pupils' take-out of books does not produce the same reading results as that of Finnish pupils.

Research and the embedding of research in schools

Nordic surveys and evaluations disclose that systematic research in the area is a condition for being able to acquire new knowledge about reading. It is also important to embed research efforts in the schools so that they can underpin teachers' expert foundation and increase their professionalism.

Several Nordic countries already undertake - and have for many years undertaken - systematic research into reading. The Norwegian reading centre in Stavanger is a good example. In Denmark, however, the investment of resources in research into reading has traditionally been much smaller, and the recommendations of the Reading Committee have made this a prioritised focus area.

The experience from the Danish Evaluation Institute's evaluations of reading in primary and lower secondary school in Denmark shows that local reading consultants are good at bridging the gap between research 
and practice, and that this is a function that it would be useful to extend. Furthermore, reading consultants provide an obvious opportunity for exchanging experience through Nordic networks, because they can both collect and communicate research and useful experience in practice from other schools. Embedding knowledge generated by research can also support greater teacher professionalism.

Focus areas of future surveys

The Nordic countries will be able to benefit from cooperation in Nordic networks on research into schooling in general and reading in particular. This will especially be the case at the practical level in terms of putting research results into new practices in the individual schools. It would be relevant to examine how research can be embedded better at school level. It will also be relevant to consider how the Nordic countries can become better at networking at both research and practice levels.

\section{Teacher professionalism}

The analysis shows that the experience and education of teachers are of importance to the teaching of reading for several reasons. Teachers holding the right qualifications reduce the risk of pupils ending up in vicious circles where reading is and becomes a complicated and long process. Also, qualified teachers can take boys' and girls' different needs into consideration in their teaching.

Focus areas of future surveys

It will be relevant to take a look at what teacher competences are required in the teaching of reading at different levels in primary and lower secondary school and then examine how to ensure that the teachers possess the right qualifications.

\section{Cooperation in specialist environments}

Teachers' specialist cooperation is important to ensure their qualifications and is thus essential to reading lesson quality. The assessment of reading in Danish primary and lower secondary schools reveals that teachers are in need of reading environments in the schools. 
Focus areas of future surveys

It will be relevant to look at how cooperation generally works at school level. For instance, focus should be on how cooperation can push teaching lessons in a positive direction through better reading environments in the schools.

\section{Reading material}

The surveys show that the reading material is crucial to pupils' reading. All surveys show that particularly boys are poor at reading fictional texts, but they are relatively better at reading schematised texts such as tables and graphs. The subjects of the texts are also of significance to the differences in reading skills. Girls are doing better than boys when the story of the text is related to people - with people as the principal characters or animals acting like human beings. Boys, however, are doing relatively better with texts without people - e.g. texts about scientific subjects.

Reading lessons in the Nordic countries often concentrate on fictional texts with children as the principal characters. As precisely this type of reading material appeals less to boys than to girls, it is evident that today's reading lessons many places do not motivate boys optimally.

Focus areas of future surveys

It will be relevant to examine what material motivates boys to a higher degree and how to include such material in lessons in a better way.

\section{Work on reading}

Processing what you have read is, according to most reading researchers, important to the development of reading skills. Exercises increasing the understanding of a text are characterised by the pupil paraphrasing what he or she has read using his or her own words. Such exercises can be both oral and written and individual, group or class exercises.

As regards the relation between reading and writing, the traditional opinion has been that reading is a condition for being able to write. However, reading researchers question this view on the basis of a more circular opinion of learning to read where several processes take place at the same time and where, on the other hand, beginning by learning to write sounds can prove an advantage. In this connection, the use of IT may also 
be important as boys can begin learning to read using the computer instead of using a book.

Focus areas of future surveys

It will be relevant to look at the options that are especially useful for boys who may find it easier to explain a text by drawing it instead of writing about it. 


\section{Appendix}

\section{Appendix A: Projektbeskrivelse}

Dette notat indeholder Danmarks Evalueringsinstituts (EVA’s) tilbud på Nordisk Ministerråds udbud af et studie af læsefærdigheder i de nordiske lande. Tilbuddet beskriver EVA's erfaringer på området og de metoder vi vil anvende for at løse opgaven.

I 2005 har EVA gennemført en del projekter og aktiviteter inden for temaerne læsning og forskelle på drenge og pigers præstationer i uddannelsessystemet. Disse projekter præsenteres nedenfor da de er væsentlige begrundelser for at EVA ønsker at give et tilbud på Nordisk Ministerråds studium.

\section{EVA's evaluering af leesning}

EVA offentliggjorde i oktober 2005 evalueringen Leesning i folkeskolen hvor formålet var at ,afdække og vurdere hvordan skoler og kommuner i et samspil arbejder med at indsamle, anvende og udvikle viden om elevernes læseindlæring“. I forbindelse med evalueringen blev der lavet en forundersøgelse der beskriver et udvalg af danske og internationale test og undersøgelser af de danske elevers læsefærdigheder fra IEAundersøgelsen i 1991 til og med Danlæs i 1999-2001.

Evalueringen af læsning viser at de relevante parter i folkeskolen (lærere, skoleledere, læsevejledere og konsulenter) er engagerede og optaget af at udvikle læseundervisningen. Den viser til gengæld også at de skoler og kommuner der deltog i evalueringen, ikke i tilstrækkelig grad inddrager viden fra blandt andet forskning og større undersøgelser på området i det konkrete arbejde på skolerne. En af de centrale anbefalinger i rapporten er at skolerne og kommunerne bør udarbejde lokale strategier for 
hvordan viden fra nationale og internationale undersøgelser inddrages i skolernes undervisning. Skoler og kommuner vil derfor kunne få stor glæde af den oversigt over relevant forskning og dokumentation på området som Nordisk Ministerråd får udarbejdet med dette studium.

EVA's undersøgelse af drenge og pigers prcestationer i uddannelse

I juni 2005 offentliggjorde EVA rapporten Køn, karakterer og karriere. Projektet er gennemført på initiativ fra Nordisk Evalueringsnetværk, der ud over EVA består af Skolverket i Sverige, Utdanningsdirektoratet i Norge og Utbildningsstyrelsen i Finland. Alle landene er i gang med eller har gennemført projekter der fokuserer på forskellen mellem drenge og pigers præstation i uddannelsessystemet, og derfor har EVA valgt at inddrage Nordisk Evalueringsnetværk i forbindelse med dette projekt for Nordisk Ministerråd. Netværkets inddragelse er beskrevet i afsnittet om projektets metode.

Rapporten Køn, karakterer og karriere indeholder dels en registerundersøgelse der viser hvordan drenge og piger præsterer ved folkeskolens afgangsprøver, ved eksamen i det almene gymnasium og i deres videre uddannelseskarriere, dels fire artikler fra udvalgte eksperter der på baggrund af registerundersøgelsen har kommenteret resultaterne og givet deres bud på hvorfor der er forskel på drenge og pigers præstationer.

Registerundersøgelsen og eksperternes artikler har ikke fokuseret på læsefærdigheder, men registerundersøgelsen viser at der er forskel på hvordan kønnene præsterer i uddannelse. For eksempel har pigerne i de to årgange af 9. klasser der indgår i undersøgelsen (årgang 1985 og 1997), et højere samlet karaktergennemsnit end drengene ved folkeskolens afgangsprøve. Undersøgelsen viser også at drengenes karakterer er mere spredte end pigernes - drengene udgør altså en mindre homogen gruppe end pigerne målt på karakterniveau.

Rapporten inddrager også tal fra Undervisningsministeriets statistikdatabase, og her viser karakterstatistikken at pigerne opnåede højere karaktergennemsnit end drengene i 2000-2004 ved afgangsprøverne i dansk (retstavning, skriftlig og mundtlig).

Med hensyn til drenge og pigers præstation i uddannelsessystemet viser registerundersøgelsen for 1985-årgangen blandt andet: 
- at der er en større andel drenge end piger der ikke når videre i uddannelsessystemet end grundskole- eller ungdomsuddannelsesniveau (gymnasiale uddannelser og erhvervsuddannelser)

- at flere piger end drenge gennemfører gymnasiet eller hf.

Forklaringer på drenge og pigers præstationer

På baggrund af EVA’s evaluering af læsning, registerundersøgelsen af drenge og pigers præstation i uddannelsessystemet og eksperternes tolkning og forklaringer af registerundersøgelsen har EVA allerede identificeret en række områder der kan forklare læsefærdigheder og forskellene i resultaterne blandt drenge og piger. EVA's undersøgelse vil tage udgangspunkt i disse områder, men også brede årsagsforklaringerne ud da områderne ikke er udtømmende.

De områder EVA har identificeret, er:

- Strukturelle forhold: nationale og kommunale tiltag, strategier og udviklingsprojekter, test af læsefærdigheder, tilsyn med skolerne, og læreruddannelsen. Desuden forklarer den socioøkonomiske sammensætning af forældre i et skoleområde hvordan skolen eller kommunen klarer sig i forhold til andre.

- Skolen: undervisningsformer, undervisningsdifferentiering, løbende evaluering, lærebogsmateriale og organisering af undervisningen ( $\mathrm{fx}$ trindelt skole).

- Køn i uddannelsesforskning: drenge og pigers fysiske og psykiske modning, hjerneudvikling og kulturelle forklaringer.

- Holdninger til læsning: at det er et indsatsområde kommunalt og nationalt, og læreres, forældres og elevers holdninger til at læse.

\section{EVA's sammenligning med PISA-undersøgelsen}

I forbindelse med Folketingets Uddannelsesudvalgs høring om PISAundersøgelsen og det danske uddannelsessystem udarbejdede EVA et indlæg der sammenligner EVA's evaluerings- og undersøgelsesresultater med PISA-undersøgelsens resultater. Her konkluderer EVA blandt andet at mens PISA-undersøgelsen viser at pigerne klarer sig dårligere end 
drengene i naturfag og matematik, så viser registerundersøgelsen bag Køn, karakterer og karriere som beskrevet ovenfor at pigerne samlet får et bedre karaktergennemsnit end drengene ved folkeskolens afgangsprøver.

Ifølge EVA skyldes forskellen mellem resultaterne af PISA-undersøgelsen og folkeskolens afgangsprøver givetvis at der er brugt forskellige metoder til at måle elevernes standpunkt: En international standardiseret test der ikke tager udgangspunkt i hverken Danmarks eller andre landes nationale læseplaner, er sat over for de nationale afgangsprøver som netop skal teste om eleverne kan det som er intentionen i læseplanerne. De forskellige målemetoder giver ikke nødvendigvis de samme resultater. Den omstændighed at målemetoden spiller ind på de resultater der opnås, skal inddrages i tolkningen af enhver undersøgelse - og dermed også i tolkningen af både PISA-undersøgelsen og resultaterne af folkeskolens afgangsprøver. Disse overvejelser vil EVA derfor også inddrage i analysen af den nordiske forskning og dokumentation på området.

\section{EVA's deltagelse i projekt om forskning og dokumentation}

EVA er allerede involveret i et projekt om forskning og dokumentation. I samarbejde med Danmarks Pædagogiske Universitet og Ministeriet for Videnskab, Teknologi og Udvikling er EVA ved at oprette et clearing house der skal følge den pædagogiske forskning nationalt og internationalt.

\section{Metode og aktiviteter}

Studiet gennemføres i tre faser der beskrives nedenfor. EVA nedsætter en nordisk ekspertgruppe der skal bidrage til studiets analyse og kvalitetssikre EVA's analyse og rapport. Ekspertgruppen vil bestå af repræsentanter for Nordisk Evalueringsnetværk, der er en arbejdsgruppe blandt EVA's nordiske søsterorganisationer fra, som tidligere nævnt, Skolverket i Sverige, Utdanningsdirektoratet i Norge og Utbildningsstyrelsen i Finland. Institutionerne har givet tilsagn om at de gerne bidrager med repræsentanter til ekspertgruppen. 
Fase 1: Deskresearch

EVA indsamler relevant nordisk forskningsmateriale og dokumentation om læsning og kønsforskelle. I forbindelse med forundersøgelsen til evalueringen af læsefærdigheder har EVA beskrevet danske og internationale undersøgelser og test.

I forbindelse med indsamlingen af relevant materiale til studiet har vi fordel af vores daglige overvågning af nye udgivelser og projekter inden for uddannelsesområdet.

Fase 2: Analyse

Når fase 1 er gennemført, afholdes det første møde med ekspertgruppen. Formålet med mødet er:

- at drøfte det indsamlede materiale og afdække om der er andre relevante nordiske undersøgelser der bør inddrages

- at diskutere hvilke problemer materialet afslører om forskelle i læsefærdigheder mellem de nordiske lande og specifikt mellem drenge og piger

- $\quad$ at formulere hypoteser der kan forklare årsager til forskelle i læsefærdigheder, blandt andet mellem drenge og piger.

Ekspertgruppens drøftelser vil tage udgangspunkt i EVA's gennemgang af det indsamlede materiale og EVA's erfaring på uddannelsesområdet generelt og specifikt i forhold til evalueringen af læsning og dreng-pigeprojektet.

Fase 3: Vurderinger og anbefalinger

På baggrund af det første møde i ekspertgruppen vil EVA beskrive og analysere undersøgelserne og dokumentationen. I analysen vil vi vurdere om den nordiske forskning på området er relevant, og i hvilken udstrækning den kan forklare forskellene i præstationer. Desuden vil vi vurdere hvilke metoder der egner sig bedst til at undersøge de opstillede hypoteser om forskellene. Dette vil blive beskrevet i et første rapportudkast.

På baggrund af det første rapportudkast indkaldes ekspertgruppen til det andet møde hvor den kvalitetssikrer EVA's vurderinger og analyse og på baggrund af udkastet kommer med anbefalinger til nye nordiske un- 
dersøgelser af læsefærdigheder og forskelle i drenge og pigers præstationer.

\section{Afrapportering}

EVA udarbejder en samlet rapport der indeholder en oversigt over relevant nordisk forskning og dokumentation og analyse, vurderinger og anbefalinger som beskrevet i fase 1-3 i dette materiale.

Rapporten vil derved være beskrivende, analyserende, vurderende og anbefalende. Denne type af rapporter har EVA stor erfaring med da tilgangen er den samme som ved de traditionelle evalueringsrapporter EVA offentliggør. EVA's evalueringsrapporter modtages generelt af et bredt modtagerfelt, fra folkeskolen til universiteter og politiske beslutningstagere fra kommunalt til nationalt niveau.

\section{Organisering}

Projektchef Lisbet Lentz er EVA’s ledelsesansvarlige på projektet. Projektets tilrettelæggelse og gennemførelse varetages af specialkonsulent Charlotte Rotbøll, der er projektleder på projektet. Desuden vil følgende blive inddraget i projektet: specialkonsulent Per Møller Janniche, der sparrer og kvalitetssikrer i forhold til undersøgelserne af læsefærdigheder, kommunikationskonsulent Charlotte Simmelhack, der dagligt overvåger ny forskning og dokumentation på uddannelsesområdet, og en evalueringsmedarbejder fra EVA's studenterkorps.

\section{Appendix B: Følgegruppen}

- Chris Silverström er specialplanerare i Utbildningsstyrelsen i Finland og er projektleder for Utbildningsstyrelsens nationale evalueringer af indlæringen i modersmål og litteratur i de svenske skoler. Han har publiceret fire nationale evalueringsrapporter om indlæring i modersmål i 7. og 9. klasse. Den seneste rapport, Modersmål och litteratur i nio år, publiceres i foråret 2006. Chris Silverström er uddannet lærer (emneslärarexamen) i modersmål og litteratur og har herefter 
været beskæftiget som forsker og talekonsulent ved Forskningscentralen för de inhemska språken og som underviser på to gymnasier.

- Karin Hector-Stahre arbejder som undervisningsråd for Skolverket i Sverige hvor hun har ansvar for nationale prøver i svensk, svensk som andetsprog for grundskolen og gymnasiet og nationale prøver i svensk for indvandrere. Hun er desuden medlem af den svenske referencegruppe for PIRLS-undersøgelsen. Karin Hector-Stahre er oprindeligt uddannet lærer og har efteruddannelse i engelsk og svensk. Hun har arbejdet som lærer i grundskolen og gymnasiet og som redaktør for tidsskriftet Svenskläraren.

- Tulle Schjerven er rådgiver hos Utdanningsdirektoratet i Norge hvor hun har opgaver inden for evaluering af nationale satsningsområder og kortlægning af læsefærdigheder. Tulle Schjerven er desuden involveret $\mathrm{i}$ en arbejdsgruppe nedsat af Nordisk Ministerråd der kortlægger hvordan undervisning i læsning bliver varetaget af læreruddannelserne i de nordiske lande. Er uddannet cand.mag. i socialantropologi, fransk og spansk og har været beskæftiget som lærer og som rådgiver i offentlige uddannelsesmyndigheder. 